\title{
Computer Simulations of Airflow and Radon Transport in Four Large Buildings
}

Jin B. Fang

Andrew K. Persily

Building and Fire Research Laboratory

Gaithersburg, Maryland 20899

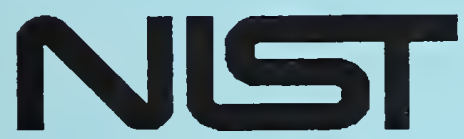

Initad States Department of Commerce

QC Iology Administration

100

ral Institute of Standards and Technology

.456

N0. 5611

1995 



\section{Computer Simulations of Airflow and Radon Transport in Four Large Buildings}

Jin B. Fang

Andrew K. Persily

\section{April 1995}

Building and Fire Research Laboratory

National Institute of Standards and Technology

Gaithersburg, MD 20899

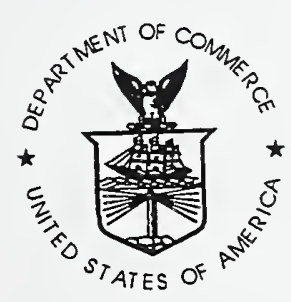

\section{U.S. Department of Commerce}

Ronald H. Brown, Secretary

Technology Administration

Mary L. Good, Under Secretary for Technology National Institute of Standards and Technology Arati Prabhakar, Director

Prepared for:

U. S. Environmental Protection Agency Office of Air and Radiation Washington, D C 



\begin{abstract}
Computer simulations of airflow and radon transport in four large buildings were performed using the multi-zone airflow and pollutant transport model CONTAM88. These buildings include a twelve-story multi-family residential building, a five-story mechanically-ventilated office building with an atrium, a seven-story mechanically-ventilated office building with an underground parking garage, and a one-story mechanically-ventilated school building. Interzone airflow rates and radon concentrations are predicted in these buildings as a function of wind speed and direction, indoor-outdoor temperature difference, and ventilation system operation. Ventilation system factors that are studied include the operation of exhaust fans in the apartment building and variations in the percent outdoor air intake in the office buildings. Simulations in the office buildings are also made with the ventilation systems off and with variations in the balance of the supply and return airflow rates.
\end{abstract}

Keywords: airflow, building technology, contaminant dispersal, indoor air quality, mechanical ventilation, modeling, multi-family residential, multi-zone, office building, radon, ventilation 


\section{TABLE OF CONTENTS}

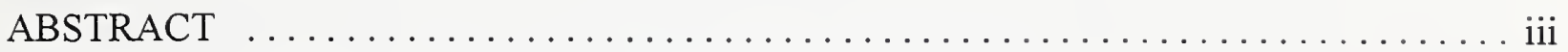

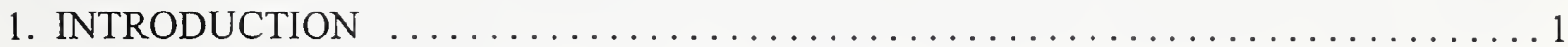

2. BUILDINGS SIMULATED . . . . . . . . . . . . . . . . . . . . . . . . 2

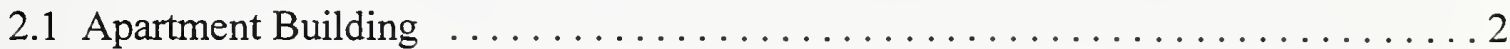

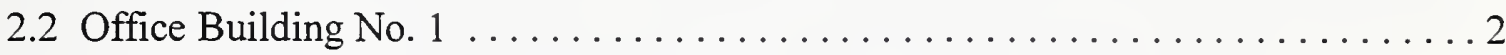

2.3 Office Building No. 2 . . . . . . . . . . . . . . . . . . . . . . . 3

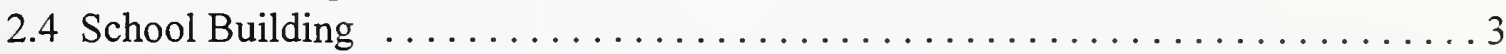

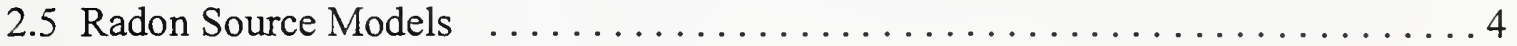

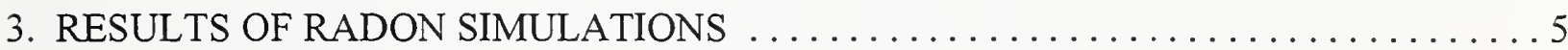

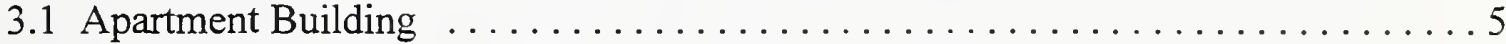

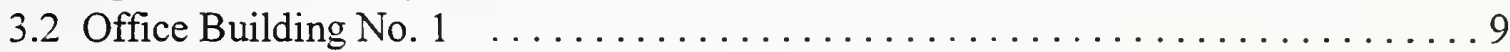

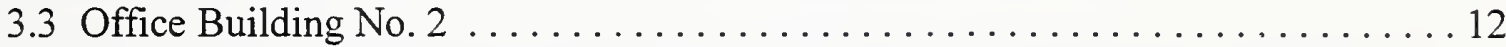

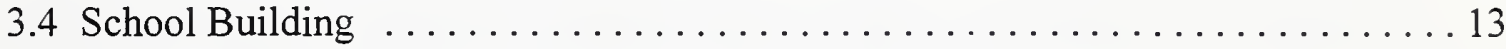

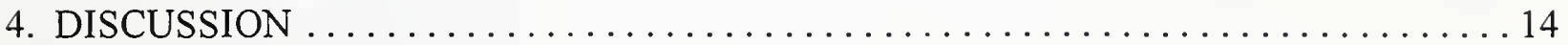

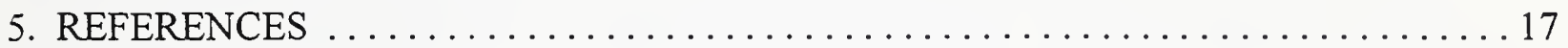

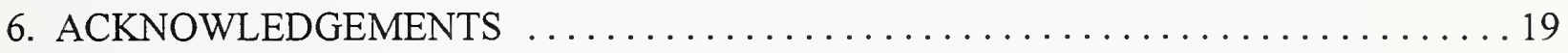

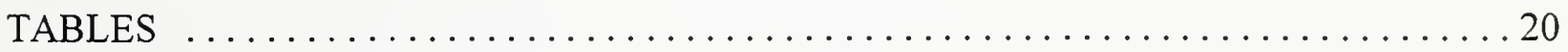

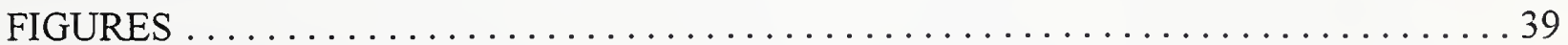





\section{INTRODUCTION}

In recent years there has been extensive research and other activities related to indoor radon levels. These activities have focused primarily on single-family dwellings as opposed to large buildings. While there is less information on radon levels in larger buildings such as schools and office buildings, these building types are currently receiving more attention than they had previously. Radon concentrations inside public and commercial buildings in the Pittsburgh area were measured by Cohen et al. (1984). The radon concentrations in these buildings had an average value of about $20 \mathrm{~Bq} / \mathrm{m}^{3}$, and were lower and less variable than the concentrations in homes in the same geographical area. A survey of radon levels in thirty-eight commercial and institutional buildings in the Pacific northwest found the average measured concentrations to be $11,26,44$, and $155 \mathrm{~Bq} / \mathrm{m}^{3}$ in the four cities where the buildings were monitored (Turk et al. 1987). Computer simulations of radon transport in a multi-story residential building were performed to study the effects of weather and selected building characteristics (Persily 1993). Radon entry and transport within large buildings can be expected to be more complex than in single-family dwellings. This increased complexity is due to the greater building heights, generally greater exposure to wind, the presence of vertical shafts such as elevators and stairways, the operation of mechanical ventilation systems, and the multi-zone nature of the airflows in these buildings.

Airflow and convective contaminant transport in multi-zone buildings are caused by pressure differences across openings in exterior and interior walls. These pressure differences are caused by wind, thermal buoyancy and mechanical ventilation system airflows. For a building with known air leakage characteristics, ventilation system airflow rates, weather conditions and contaminant source strengths, multi-zone airflow and contaminant dispersal models can predict the airflow rates from one building zone to another (including to and from the outdoors) and the contaminant levels in each zone. In these models, a zone is a portion of a building at a uniform temperature, pressure and contaminant concentration that exchanges air and contaminants with other building zones. These zones are not necessarily the same as the thermal zones of the HVAC system, but are related to the HVAC zoning, the building configuration and the purpose of the analysis. Several models have been developed for predicting airflow, contaminant dispersal and fire-induced smoke movement in multi-zone buildings. These multi-zone airflow and contaminant dispersal models were reviewed by Feustel and Kendon (1985), Feustel and Dieris (1992), Austin et al. (1992), Haghighat (1989) and Said (1988). These models use a network approach to obtain a set of nonlinear equations derived from a mass balance in each zone and an iterative solution technique based on the Newton-Raphson method to solve for the pressure at each node. These pressures are then used to calculate the steady-state airflow rates to and from each zone based on the given leakage values. The models then calculate contaminant concentrations in each building zone using these airflow rates, contaminant source strengths and information on other contaminant transport mechanisms. The models are essentially the same in the mass balance approach used, with differences primarily in the input and output interfaces and some of the details of the models.

This report presents the results of multi-zone simulations of airflow and radon transport in four large buildings using the program CONTAM88 (Grot 1991). The four buildings that 
were modeled include a twelve-story apartment building, a five-story mechanically-ventilated office building with an atrium, a seven-story mechanically-ventilated office building with an underground parking garage, and a one-story school building. The objective of these simulations was to identify some of the important factors influencing radon entry and transport in large buildings, not to predict actual radon exposure to the building occupants. These simulations address only a limited number of the many factors that could influence indoor radon levels and necessarily require many assumptions concerning building air leakage characteristics and radon source strengths. The model input values were not selected to represent specific buildings, but are expected to yield reasonable values of building airflow rates and radon concencentrations. The predicted radon concentrations from any particular simulation should only be considered in relation to other simulations of the same building and should not be generalized to other buildings.

The first section of this report describes the physical characteristics of the four buildings and the manner in which they were idealized as multi-zone airflow systems within CONTAM88. This section also describes two radon entry models employed in the simulations. The second section of the report presents the results of the radon modeling for the four buildings. These results enable the examination of the effects of wind speed and direction, indoor-outdoor temperature difference, ventilation system operation, and the form of the radon source model on the predicted indoor radon levels and building air change rates.

\section{BUILDINGS SIMULATED}

This section contains brief descriptions of the four buildings that were modeled in this study and how they were represented in CONTAM88. More detailed information on the buildings is contained in Fang and Persily (1994). The pressure-dependent and pressureindependent radon source models that were used in the simulations are also described.

\subsection{Apartment Building}

The apartment building consists of twelve-stories and a basement, and is based on a simplified representation employed previously to model air and radon transport in a multi-story residential building (Persily 1993). A typical floor plan of this building is shown in Figure 1. Each typical story (second through twelfth floors) of the building has four apartments, with two on each side of a central hall. The first floor contains a large lobby with a main entrance at the center of the west exterior wall and two apartment units on the east side. The building has an elevator shaft and a stairwell located at the ends of the hall. Both of these shafts extend from the basement to the roof.

\subsection{Office Building No. 1}

Office Building No.1 is a seven-story, mechanically-ventilated building based on an office building located in Overland, Missouri that was the subject of a study of building ventilation and indoor air quality (Persily et al. 1991 and 1992). The building consists of five floors above grade and two floors, levels B1 and B2, that are below grade. A schematic floor 
plan of level 5 is shown in Figure 2. The building is square in shape and has an atrium extending from the first floor to the roof. The total floor area is about $32500 \mathrm{~m}^{2}$, and the volume is about $122000 \mathrm{~m}^{3}$. Stairwells are located in each corner of the building, and there are six passenger elevators and a freight elevator in the south comer.

The building has a decentralized ventilation system with two variable-air-volume air handling systems serving each floor and one additional system serving the atrium, for a total of 15 air handlers in the building. Two toilet exhaust fans are located on the roof and serve each floor through a common duct. Return air from the occupied spaces flows through a return air plenum above the suspended ceiling and back to the air handlers, where it is either recirculated into the supply air or exhausted to the outdoors.

\subsection{Office Building No. 2}

Office Building No. 2 is a seven-story, mechanically-ventilated building with a two-story underground parking garage. It is based on an office building in Portland, Oregon that was the subject of a study of ventilation and indoor air quality (Grot et al. 1989, Dols and Persily 1992). These references contain detailed descriptions of the building, including floor plans and ventilation system design information. A schematic elevation of the building is shown in Figure 3 , and a typical floor plan is shown in Figure 4. The building has a conditioned floor area of about $42900 \mathrm{~m}^{2}$ and a building volume of approximately $183600 \mathrm{~m}^{3}$. Eight passenger elevators and a freight elevator are located on the east side of the building. Stairways are located on both the east and west sides of the building. A two-story parking garage is connected to the occupied spaces by two stairways and four passenger elevators.

There are three variable-air-volume air handlers in the penthouse mechanical room that serve all seven above-grade floors. A separate air handling unit is located on and serves the B1 level. Two toilet exhaust fans are located on the roof and serve each floor through a common duct. The underground garage has four exhaust fans. As in the case of Office Building No.1, return air from the occupied spaces flows through a return air plenum above the suspended ceiling and back to the air handlers, where it is either recirculated into the supply air or exhausted to the outdoors.

\subsection{School Building}

The school building is a one-story, mechanically-ventilated building consisting of classrooms, conference rooms, offices, storage rooms, corridors, toilets, a kitchen, an all-purpose room and a boiler room. This building is based on an elementary school building located in Montgomery County, Maryland. A floor plan of the school is shown in Figure 5. The numbers in the figure refer to the 55 zones in the CONTAM88 simulation. The building has a central courtyard, a floor area of about $3990 \mathrm{~m}^{2}$, and a building volume of approximately $15050 \mathrm{~m}^{3}$. 
The ventilation system in this building consists of a combination of unit ventilators, supply air handlers and exhaust fans. Individual unit ventilators are mounted in the exterior walls of classrooms and several offices and storage rooms. An individual supply air handler serves the general office space. The building also has nine ducted exhaust systems that serve various combinations of rooms in the building. There are sixteen local exhaust fans that serve the kitchen, general office space and conference and storage rooms.

\subsection{Radon Source Models}

This section describes the two radon entry models used in the simulations. One model assumes that the radon entry rate is dependent on pressure, while the second is based on a pressure-independent radon source. The first model assumes that the radon entry rate through the building foundation depends on the pressure difference between the basement floor and the outdoors. In this simplified model, described in more detail in Persily (1993), the radon entry rate when $\Delta \mathrm{P}$ is negative is equal to

$\mathrm{R}_{1} \mathrm{~A} \Delta \mathrm{P}^{\mathrm{n}}$

where $R_{1}$ is the radon entry coefficient, $A$ is the basement floor area, $\Delta P$ is the pressure difference between the basement floor and the outdoors, and $\mathrm{n}$ is the pressure exponent. When $\Delta \mathrm{P}$ is positive, i.e., the basement is at a higher pressure than outdoors, the radon entry rate is equal to zero. The value of the radon entry coefficient $R_{1}$ used in these simulations is $0.02 \mathrm{~Bq} / \mathrm{s}$ $\mathrm{Pa}$ per $\mathrm{m}^{2}$ of basement floor area, and the pressure exponent is assumed to equal 1.0. The radon source model also requires an air leakage coefficient for the airflow path from the basement floor, through the soil, and to the outdoors. A leakage area of $0.0085 \mathrm{~cm}^{2}$ per m $\mathrm{m}^{2}$ of basement floor area and a pressure exponent of 1.0 were used in these simulations.

The second radon entry model is based on the assumption that the radon entry rate is independent of the pressure difference between the basement and the outdoors. In this model, also described in Persily (1993), the radon entry rate when $\Delta \mathrm{P}$ is negative is equal to

$$
\mathrm{R}_{2} \mathrm{~A}
$$

where $R_{2}$ is the radon entry coefficient. When $\Delta P$ is positive, the radon entry rate is equal to zero. In these simulations, the pressure independent entry coefficient $R_{2}$ is equal to $0.05 \mathrm{~Bq} / \mathrm{s}-\mathrm{m}^{2}$ of floor area, and the leakage area of the basement floor is the same as in the pressure dependent model. The numerical values $R_{1}$ and $R_{2}$ are based on the source strength that corresponds to an indoor radon concentration of about $150 \mathrm{~Bq} / \mathrm{m}^{3}$ in a single-family residential building with typical airtightness based on the results of simulations using CONTAM88 (Persily 1993). These radon entry models are obviously oversimplified representations of an extremely complex phenomena. They do not include important parameters such as soil radium content and permeability, temporal and spatial variations in these parameters, and the nature and extent of the cracks in the building-soil boundary. More complete models of radon entry are described in Gadgil (1992) and Revzan et al. (1991). 
These radon entry models were implemented within CONTAM88 through the use of socalled "soil zones" located beneath each of the building zones on the lowest level of each building. These soil zones are connected to the building zones by airflow paths with very low resistance to airflow and are connected to the outdoors by an airflow resistence equal to the basement floor area multiplied by $0.0085 \mathrm{~cm}^{2} / \mathrm{m}^{2}$.

\section{RESULTS OF RADON SIMULATIONS}

In order to gain insight into the factors affecting radon entry and transport in multi-zone buildings, a number of computer simulations were performed for the four large buildings described in the previous section. These simulations examined the effects of weather conditions and other parameters on interzone airflow patterns and radon concentrations. Table 1 is a list of the simulations performed in the four buildings. The simulations in the apartment building were run at a series of indoor-outdoor temperature differences ranging from -10 to $30^{\circ} \mathrm{C}$ and wind speeds from 0 to $10 \mathrm{~m} / \mathrm{s}$ for the two radon source models. This range was selected to examine the impacts of wind and temperature, not to represent any particular geographic location. The effects of exhaust fans operating in the individual apartments and of two wind directions were also examined. In the two office buildings, the simulations were run for three levels of outdoor air intake and with the ventilation systems off. These cases were analyzed over a range of indoor-outdoor temperature differences and wind speeds. The influences of different ratios of supply and return airflow rates were examined for Office Building No. 1. Radon levels in the school building were calculated for a range of weather conditions, at three levels of outdoor air intake, and with the ventilation systems off. In all of the simulations, indoor air temperatures were fixed at $23{ }^{\circ} \mathrm{C}$ in all building zones and the outdoor radon concentration was set equal to $10 \mathrm{~Bq} / \mathrm{m}^{3}$.

This section presents the simulation results for the four buildings based on the output of CONTAM88. The CONTAM88 output includes interzone airflow rates between all building zones, and the pressure and radon concentration in each zone. This section summarizes the output in terms of whole building outdoor air change rates, pressure differences between the basement floor and the outdoors, radon entry rates into the building, and radon concentrations in selected building zones.

\subsection{Apartment Building}

This section discusses the simulation results for the apartment building presented in Tables 2 through 12. The first column of these tables lists either the indoor-outdoor temperature difference or the wind speed, depending on the case being presented. The next three columns contain the whole building air change rate, the pressure difference between the basement floor and the outdoors, and the rate at which radon enters the basement. The last four columns contain the radon concentration in the basement, the average concentrations for the second and twelfth floor apartments, and the average concentration for all of the apartments in the building. For the simulation results presented in Tables 2 through 6 and in Tables 11 and 12, the radon entry rate is assumed to be dependent on the pressure difference across the basement floor. The simulations in Tables 7 through 10 are based on the pressure-independent radon entry model. 
Table 2 shows the results with no wind for indoor-outdoor temperature differences of -10 , $0,10,20$ and $30^{\circ} \mathrm{C}$. These simulations clearly show the impact of the stack effect on radon entry and air movement within a tall building. At a negative temperature difference, the basement is pressurized by the stack effect and no radon enters the building. For positive temperature differences, the stack effect depressurizes the basement, pulling radon into the building. Since the magnitude of the stack-induced depressurization of the basement increases with temperature difference, the radon entry rate also increases with temperature difference. These increased entry rates result in increased radon concentrations as a function of temperature difference for the basement, the twelfth-story apartments and the building average. Although the building air change rate also increases with temperature difference, its rate of increase as a function of temperature difference is less than the rate at which the radon entry increases with temperature difference. As a result, the indoor radon concentrations increase with temperature-difference even though the rate of outdoor air dilution is also increasing. No radon ever reaches the second floor apartments due to stack-driven flow from the basement and lower floors into the stairwell and elevator shafts and then out of these shafts into the upper floors. This airflow pattern is another important manifestation of the stack effect in tall buildings with vertical shafts, i.e., airflow into the shafts on lower floors and out of the shafts on upper floors. The indoor radon concentrations are greater than the outdoor concentration of $10 \mathrm{~Bq} / \mathrm{m}^{3}$ on the second floor for a temperature difference of $-10^{\circ} \mathrm{C}$, and less than $10 \mathrm{~Bq} / \mathrm{m}^{3}$ for positive temperature differences, due to the density difference between the indoor and outdoor air.

Tables 3 through 5 contain the simulation results as a function of wind speed for indooroutdoor temperatures of $-10,0$ and $10^{\circ} \mathrm{C}$ respectively. In all of these simulations, the wind direction was from the north. In these simulations, it is seen that wind tends to depressurize the building, pulling radon into the basement and then vertically to the upper floors. This windinduced depressurization effect is superimposed on the stack effect described previously to determine the pressure difference across the basement floor, and therefore the radon entry rates, and the pattern of radon transport from the basement to the other building zones.

As illustrated in Table 3 for a temperature difference of $-10^{\circ} \mathrm{C}$, no radon enters the building until the wind speed reaches $8 \mathrm{~m} / \mathrm{s}$. At lower wind speeds, the downward flow of air caused by the stack effect pressurizes the basement, preventing radon entry into the basement from the soil. As the wind speed increases, the pressurization of the basement decreases until it becomes negative at $8 \mathrm{~m} / \mathrm{s}$ and radon enters the building. In essence, the stack effect tends to pressurize the basement and the wind tends to depressurize the building, and these two effects compete. The stack effect dominates at lower wind speeds and the wind effect dominates at higher wind speeds. For cases in which radon enters the building, the average radon levels are only slightly above outdoors and the radon never reaches the twelfth-floor. In fact, downward flow induced by the stack effect keeps the radon out of all but the first and second floor apartments for this range of wind speeds.

At a temperature difference of $0{ }^{\circ} \mathrm{C}$, shown in Table 4, radon enters the basement due to wind-induced depressurization for all non-zero wind speeds. Basement depressurization, the radon entry rate, the radon concentrations in the basement and second-story apartments, and the building average concentration all increase with wind speed. For cases with nonzero wind 
speeds, the average radon levels are very close to the outdoor levels. As seen in the table, the twelfth floor is at the outdoor concentration. In fact, most of the apartments are at the outdoor concentration because the interzone airflow pattern induced by the wind prevents the transport of radon to these floors. Only a small number of apartments on the lower floors have radon concentrations above outdoors.

At a temperature difference of $10^{\circ} \mathrm{C}$, radon enters the basement at all wind speeds and its entry rate increases with wind speed as shown in Table 5. At low wind speeds, the stack effect transports radon from the basement to the upper floors, bypassing the lower floors of the building. At wind speeds of $8 \mathrm{~m} / \mathrm{s}$ and above, radon reaches the second floor and other lower floors, due to the wind-induced depressurization of these floors. Twelfth-floor radon levels and the average of all apartments decrease with wind speed because the rate of outdoor air dilution increases faster than the rate of radon entry.

Table 6 shows the results for the apartment building with a $47 \mathrm{~L} / \mathrm{s}$ exhaust fan operating in each apartment for a range of indoor-outdoor temperature differences and no wind. At a temperature difference of $-10^{\circ} \mathrm{C}$, the stack effect pressurizes the basement and no radon enters the building. For non-negative temperature differences, the basement is depressurized and the radon entry rate increases with temperature difference due to the stack effect. These increases in entry rate result in increased radon concentrations for the twelfth-story apartments and the overall average of all apartments. As in the case with no exhaust fans, no radon from the soil zone appears in the second-story apartments at any temperature difference due to the stack-driven airflow patterns. The radon entry rates are higher than the corresponding cases with no exhaust fan (see Table 2), because the operation of the exhaust fans lowers the basement pressure. However, the operation of the exhaust fans increases the outdoor air change rates more than the radon entry rates, resulting in lower radon concentrations in all zones except the basement.

The simulations presented in Tables 7 through 10 employed the pressure-independent radon source model in which the radon entry rate depends only on the sign of the pressure difference across the basement floor. Table 7 shows the predicted radon concentrations in the building with the pressure-independent source for no wind under a range of indoor-outdoor temperature differences. As shown in the table, no radon from the soil enters the basement for temperature differences less than or equal to zero. For positive temperature differences, the radon entry rate is constant, and the radon concentrations in the building decrease with temperature difference as the building air change rate increases. No radon reaches the apartments on the second floor due to the stack effect. The twelfth-story radon concentrations and the average of all apartments decrease with increased temperature difference due to increased dilution with outdoor air.

Tables 8 through 10 contain the predicted radon concentrations for the pressureindependent radon source as a function of wind speed for temperature differences of -10, 0 and $10^{\circ} \mathrm{C}$ and a wind direction from the north. As shown in Table 8, no radon from the soil zone enters the basement for a temperature difference of $-10^{\circ} \mathrm{C}$ until the wind speed increases to 8 $\mathrm{m} / \mathrm{s}$. At lower wind speeds, the stack effect produces a positive pressure in the basement relative to the soil, preventing radon from entering the building. At higher wind speeds, the wind- 
induced depressurization of the building draws soil gas into the basement. The impact of wind and temperature on building airflows and pressures is identical to the case of the pressuredependent radon source presented in Table 3. Also as seen in Table 3, for those cases in which radon enters the building, the average radon levels are only slightly above outdoors and the radon never reaches the twelfth floor. In fact, downward flow induced by the stack effect keeps the radon out of all but the first and second floor apartments for this range of wind speeds. In contrast to the results in Table 3 , the radon concentrations decrease with wind speed from 8 to 10 $\mathrm{m} / \mathrm{s}$ as the outdoor air change rate increases but the radon entry rate is constant.

Table 9 shows the simulation results for a temperature difference of $0{ }^{\circ} \mathrm{C}$. In this case, radon enters the building for wind speeds greater than $0 \mathrm{~m} / \mathrm{s}$ due to wind-induced depressurization. The basement, second floor, and apartment average radon concentrations decrease with wind speed, since the outdoor air change rate increases and the radon entry rate is constant. As was the case for the pressure-dependent source in Table 4, the indoor radon concentrations for cases with nonzero wind speeds are very close to the outdoor levels. Most of the apartments are at the outdoor concentration due to the wind-induced interzone airflow pattern in the building. Only a small number of apartments on the lower floors have radon concentrations above outdoors.

At a temperature difference of $10{ }^{\circ} \mathrm{C}$, radon enters the basement at all wind speeds as illustrated in Table 10. As was the case with the pressure-dependent source, radon from the soil does not get to the second floor until the wind speed reaches $8 \mathrm{~m} / \mathrm{s}$. At these higher wind speeds, wind-induced depressurization overcomes the upward airflow caused by the stack effect. Twelfth-story radon concentrations and the average of all apartments decrease with wind speed as the outdoor air change rate increases.

Tables 11 and 12 contain the predicted radon concentrations for the apartment building with the pressure dependent radon source and wind approaching $90^{\circ}$ from the north (i.e., from the east) for temperature differences of 0 and $10^{\circ} \mathrm{C}$. Qualitatively the results in Tables 11 and 12 are similar to those for the wind from the north shown in Tables 4 and 5, except the $90^{\circ}$-wind induces less depressurization of the basement. The depressurization is less for the $90^{\circ}$-wind due to the specific values of the surface wind pressure coefficients used in the model. For a temperature difference of $0{ }^{\circ} \mathrm{C}$, the radon entry rate and the indoor radon concentrations increase with wind speed. The radon is confined to the lower floors of the building due to the windinduced airflow patterns. For a temperature difference of $10 .{ }^{\circ} \mathrm{C}$, the radon entry rate also increases with wind speed, but the radon concentrations decrease due to a faster rate of increase in the building air change rate compared to the increase in the radon entry rate. Radon reaches the second floor for wind speeds of $6 \mathrm{~m} / \mathrm{s}$ and above, and the radon concentration on this floor increases with wind speed, as wind-induced depressurization of this floor causes airflow from the basement. 


\subsection{Office Building No. 1}

This section presents the results of the simulations in Office Building No. 1 for various conditions of wind speed and direction, indoor-outdoor temperature difference, and ventilation system operation. The ventilation system parameters include whether the system was on or off, the percentage of outdoor air intake, and the balance of the supply and return airflow rates.

Table 13 shows the simulation results at minimum outdoor air intake (corresponding to about $18 \%$ outdoor air in the supply air and about 0.65 air changes per hour) and zero wind speed for a range of temperature differences. In this table, the first four columns contain the indooroutdoor temperature difference, the whole building air change rate, the pressure difference between the basement floor and the outdoors, and the radon entry rate into the basement. The table also contains the radon concentrations in the lowest basement level (B2), in the first and fifth floor occupied space, and the average of all occupied spaces in the building. The average is based on the occupied portions of all floors including the two basement levels, which contain office space in the building upon which Office Building No. 1 is based. The simulations presented in Tables 13 through 27 assume that the supply airflow rate into each occupied zone is $10 \%$ greater than the return airflow rate out of the zone. Table 13 shows that for temperature differences less than or equal to zero, the basement is at a positive pressure relative to the outdoors due to the stack effect and due to the excess of the supply airflow rate relative to the return airflow. Given the pressurization of the basement, no radon enters the building. When the temperature difference is positive, the basement is depressurized by the stack effect, and radon is pulled into the building. The basement depressurization and the radon entry rate increase with temperature difference. These increases result in higher radon concentrations in the basement, on the fifth floor and for the average of all occupied spaces. The predicted air change rate varies little with temperature difference because the outdoor air change is dominated by the outdoor air intake of the mechanical system, i.e., there is little envelope infiltration. The changes in radon concentration as a function of temperature difference are attributable primarily to changes in the radon entry rate. No radon reaches the first floor occupied space at any temperature difference because the stack effect induces airflow from the lower floors into the stair and elevator shafts and from these shafts into the upper floors.

Table 14 shows the predictions for Office Building No. 1 at minimum outdoor air intake for wind speeds from 0 to $10 \mathrm{~m} / \mathrm{s}$. In these simulations the wind direction was from the north and the indoor-outdoor temperature difference was $10^{\circ} \mathrm{C}$. The basement is depressurized due to the stack affect, and radon enters the building at all wind speeds. However, the degree of basement depressurization and the radon entry rate decrease with increasing wind speed. The building pressure increases with wind speed because of the nonlinear nature of the airflow paths combined with a net airflow into the building by the mechanical system. The decreasing radon entry rates result in decreasing radon concentrations in the building. Due to the stack-driven airflow patterns from the lower floors into the shafts, no radon reaches the first floor of the building. 
Tables 15 and 16 show the simulation results with the ventilation systems off at indooroutdoor temperature differences of $0{ }^{\circ} \mathrm{C}$ and $10^{\circ} \mathrm{C}$ respectively. Table $15\left(0{ }^{\circ} \mathrm{C}\right)$ shows that radon enters the building at wind speeds greater than or equal to $2 \mathrm{~m} / \mathrm{s}$. The radon entry rates are low, and almost no radon reaches the occupied portions of the first and higher floors. The depressurization of the basement is minimal, with very little dependence on wind speed. The entry rate does increase with wind speed as wind-induced depressurization increases, resulting in increasing radon concentrations as a function of wind speed.

As illustrated in Table 16, radon enters the building at all wind speeds with the fans off and a temperature difference of $10^{\circ} \mathrm{C}$. The radon entry rate is induced by the stack effect and is much higher than at a temperature difference of $0{ }^{\circ} \mathrm{C}$. The basement pressure and the radon entry rate are almost independent of wind speed. The radon concentrations in the basement and the fifth floor occupied space and the building average concentration decrease with wind speed due to the increased outdoor air change rate. Due to the stack-induced airflow patterns in the building, radon does not reach the first floor occupied space at any wind speed.

Tables 17 and 18 show the results for $50 \%$ and $100 \%$ outdoor air intake (corresponding to about 1.75 and 3.50 air changes per hour) and an indoor-outdoor temperature difference of $10{ }^{\circ} \mathrm{C}$. As shown in these tables, the dependence of basement depressurization and radon entry rate on wind speed is the same for both cases. In fact, the values of basement pressure and radon entry rate are the same as for the case of minimum outdoor air intake in Table 14. This identical relationship exists because the same ratio of supply and return airflow rates was assumed to exist (i.e., input into the model) for all three cases, that is, the outdoor air intake and the rate at which return air is exhausted by the air handlers both increase at the same rate. As noted earlier, the basement depressurization and radon entry rate decrease with wind speed as a result of the nonlinear nature of the airflow paths combined with a net airflow into the building by the mechanical system. The decrease in radon entry rate with wind speed, combined with a slight increase in the outdoor air change rate with wind, results in reduced radon concentrations in the basement, the fifth floor occupied space, and the whole building average. The radon levels are lower for the case of $100 \%$ outdoor air intake than for $50 \%$ intake due to the increase in outdoor air dilution. No radon reaches the first floor occupied areas due to the stack-induced airflow pattern in the building.

Tables 19 through 22 show the simulation results for a wind direction of $45^{\circ}$ from the north (from the northeast) and a temperature difference of $10^{\circ} \mathrm{C}$. These tables include ventilation system operating conditions of fans off (Table 19), minimum outdoor air intake (Table 20), 50\% outdoor air intake (Table 21) and 100\% outdoor air intake (Table 22). As seen in Table 19, radon enters the building at all wind speeds when the fans are off, and the basement depressurization and radon entry rate increase with wind speed. This increase in radon entry with wind speed contrasts with the case of the wind from the north in which the basement depressurization and radon entry are almost independent of the wind speed (Table 16). This directional effect on building pressure exists due to the specific values of the surface wind pressure coefficients assumed in the model for these two different values of wind direction. For wind speeds of $6 \mathrm{~m} / \mathrm{s}$ and above, the building average concentration increases with wind speed as the increasing radon entry rate dominates over the increasing rate of outdoor air dilution. 
However, this effect is not uniform throughout the building. The fifth floor radon concentration decreases with increasing wind speed because of greater outdoor air dilution relative to the radon transport to this floor. Radon does not appear on the first floor occupied space due to the stackinduced airflow pattern in which air flows from the lower floors into the veritical shafts.

With the ventilation system operating, radon from the soil zone enters the building at all wind speeds as illustrated in Tables 20 through 22. As was the case with the wind from the north (Tables 14, 17 and 18), the basement pressures and radon entry rates are identical for all three levels of outdoor air intake because the same supply and return airflow rates were assumed to exist for all levels of outdoor air intake. The extent of basement depressurization and the radon entry rate decrease with wind speed from 0 to $4 \mathrm{~m} / \mathrm{s}$, and then increase with wind speeds for 6 $\mathrm{m} / \mathrm{s}$ and above. This dependence of basement pressure on wind is in contrast to the case of wind direction from the north in which the basement pressure increases continually with wind speed. The dependence of basement pressure on wind seen in Tables 20 through 22 occurs due to nonlinear effects of wind pressures, the leakage characteristics of the exterior walls and the mechnically-induced airflow into the building.

For the case of minimum outdoor air intake (Table 20), a small amount of radon from the soil zone appears on the first floor occupied space at wind speeds greater than $4 \mathrm{~m} / \mathrm{s}$. No radon ever reaches the first floor for cases with $50 \%$ and $100 \%$ air intake. This difference occurs due to the complexities of the interzone airflow patterns for the cases examined. For all levels of outdoor air intake, the basement, fifth floor and building average radon levels decrease as the wind speed increases from $0 \mathrm{~m} / \mathrm{s}$ and then increase after reaching a minimum value at 2 or $4 \mathrm{~m} / \mathrm{s}$.

Tables 23 and 24 contain the simulation results with the ventilation system operated with balanced or equal supply and return airflows and with a $10 \%$ lower supply airflow rate relative to the return airflow rate. The predicted results for all of the previously discussed cases assumed that the supply airflow rate was $10 \%$ larger than the return airflow rate. In the simulations presented in Tables 23 and 24 , the indoor-outdoor temperature difference is equal to $10^{\circ} \mathrm{C}$, the wind direction is from the north and the system is operating at minimum outdoor air intake.

In Table 23, the basement depressurization and radon entry rate increase gradually with wind speed. Radon from the soil does not reach any building floor other than the basement for balanced supply and return airflows. For all values of wind speed, air from the basement leaves the floor only through the ventilation system return and does not flow into any of the vertical shafts. For the cases with $10 \%$ oversupply relative to return, air from the basement flowed into the verticial shafts and then vertically to the upper floors of the building. When the supply airflow rate is $10 \%$ below the return airflow rate, the interzone airflow pattern is similar to the balanced ventilation case. Air leaves the basement only through the system return, and as seen in Table 24, radon from the soil reaches only the basement zone. The basement depressurization and radon entry rate for this case is larger than for balanced ventilation. Also, the building air change rate is constant at all wind speeds shown, and the basement pressure changes little with wind speed. 


\subsection{Office Building No. 2}

Table 25 presents the simulation results for Office Building No. 2 as a function of temperature difference with no wind, minimum outdoor air intake (corresponding to about $3 \%$ outdoor air in the supply air and 0.11 air changes per hour) and the garage exhaust fans operating. As was the case for Office Building No. 1, the building average is based on all floors including the $\mathrm{B} 1$ (basement) level since it was occupied in the actual building. The simulations in Office Building No. 2 at minimum outdoor air intake assume that the supply airflow rate is about 3.5\% larger than the return airflow rate. The simulations at $50 \%$ and $100 \%$ outdoor air intake assume that the supply airflow rate is about $16 \%$ larger than the return airflow rate. As seen in Table 25, radon enters the underground garage from the soil at all temperature differences due to the depressurization of the garage by the exhaust fans. The radon entry rate and the radon concentration in the garage increase with temperature difference due to the stack effect. This radon does not reach the $\mathrm{B} 1$ level or the seventh floor until the temperature difference is greater than $10^{\circ} \mathrm{C}$. At lower values of the temperature difference, the garage exhaust fans and the stack effect prevent airflow from the garage to other building floors.

Tables 26 through 28 show the simulation results as a function of wind speed for three levels of outdoor air intake: minimum, $50 \%$ and $100 \%$. Outdoor air intake levels of $50 \%$ and $100 \%$ correspond to about 1.66 and 3.30 air changes per hour. These simulations were performed at a temperature difference of $30^{\circ} \mathrm{C}$ and with the garage exhaust fans operating. As indicated in the tables, radon from the soil enters the garage at all wind speeds. As the wind speed increases, the depressurization of the basement and the radon entry rate also increase. For the case with minimum outdoor air, shown in Table 26, radon reaches the B1 level and the seventh floor for wind speeds less than $8 \mathrm{~m} / \mathrm{s}$, but at higher wind speeds no radon from the garage reaches any of the other building floors. For cases with $50 \%$ and $100 \%$ air intakes, shown in Tables 27 and 28, radon from the garage never reaches the B1 level at any wind speed. A small amount of radon reaches the seventh floor only for wind speeds less than or equal to $2 \mathrm{~m} / \mathrm{s}$.

Tables 29 and 30 show the simulation results with the fans off and a temperature difference of $30^{\circ} \mathrm{C}$ for wind directions of north and $45^{\circ}$ from the north (from the northeast). Radon enters the building at all wind speeds, and the entry rate and concentration increases with wind speed due to wind-induced depressurization of the building with one striking exception. With the wind from the north, radon no longer reaches any of the occupied floors when the wind speed reaches $10 \mathrm{~m} / \mathrm{s}$. At lower wind speeds, air flows from the garage into the building shafts, and from the shafts into the upper building floors, but the direction of these airflows changes dramatically when the wind speed increases from 8 to $10 \mathrm{~m} / \mathrm{s}$. There is no physically intuitive explanation for this change; it is presumably a manifestation of the complex, nonlinear nature of these airflows. In the case of wind direction of $45^{\circ}$ from the north, the radon concentrations in the garage, the seventh floor and the building average increase with wind speed. Radon from the garage never reaches the $\mathrm{B} 1$ level at any wind speed for both wind directions.

Tables 31 through 33 show the results for a wind direction of $45^{\circ}$ from north at a temperature difference of $30^{\circ} \mathrm{C}$ and three levels of outdoor air intake: minimum, $50 \%$ and $100 \%$. As seen in these tables, radon from the soil enters the building at all wind speeds, and both the 
entry rates and the garage concentrations increase with wind speed. Basement pressures and radon entry rates are somewat lower than for the corresponding cases with a wind direction from the north (Tables 26 through 28). With minimum air intake, more radon reaches the seventhfloor and the concentration decreases with wind speed as the rate of outdoor air dilution increases.

\subsection{School Building}

The simulation results for the school building are shown in Figure 6 at $50 \%$ outdoor air intake, no indoor-outdoor temperature difference and zero wind speed. This figure shows the radon concentration in each zone and the pressure difference between the floor of each zone and the outdoors. As shown in the figure, all but three of the building zones are depressurized by the ventilation systems. The pressure in each zone, and hence the radon entry rate, depends on the supply airflow rate into each zone relative to the exhaust plus return airflow rate out of the zone. There is a wide variation in the radon entry rate and radon concentration in the building zones due to variations in the mechanical ventilation airflow rates of the zones.

Table 34 shows the simulation results for the school building with outdoor air intake rates of $25 \%, 50 \%$ and $75 \%$ and a temperature difference of $30{ }^{\circ} \mathrm{C}$ with no wind. In this table, the third through fifth columns contain the maximum, minimum and average pressure difference between the floor of each zone and the outdoors. These three values are based only on the occupied zones in the building. The fourth column is the total radon entry rate into the building. The last three colums contain the maximum, minimum and the average radon concentration for all of the occupied zones. As illustrated in the table, all zones are depressurized at $25 \%$ outdoor air intake. At $50 \%$ and $75 \%$ outdoor air intake, several of the occupied zones are positively pressurized. The radon entry rate and the indoor radon concentrations decrease as the outdoor air intake percentage increases due to the pressurization of the building by the increased air intake.

Table 35 contains the simulation results for indoor-outdoor temperature differences of 0 and $30{ }^{\circ} \mathrm{C}$ and wind speeds of 0 and $10 \mathrm{~m} / \mathrm{s}$ at $50 \%$ outdoor air intake. At a fixed temperature difference, an increase in wind speed from 0 to $10 \mathrm{~m} / \mathrm{s}$ increases the building depressurization on the average, although the wind effects on an individual zone depends on its orientation and exposure relative to the wind direction. The increased depressurization of the building with wind increases the radon entry rate. The building air change rate also increases with wind speed, but not as much as the entry rate, and therefore the radon concentrations in the building increase with wind. The increase in air temperature difference from 0 to $30^{\circ} \mathrm{C}$ increases the building depressurization and radon entry rate slightly and reduces the building air change rate, resulting in increased radon concentrations.

Table 36 presents the results as a function of temperature difference with the fans off and zero wind speed. No radon entry occurs for temperature differences less than or equal to zero due to the stack effect. For positive temperature differences, the building depressurization and radon entry rate increase with temperature difference due to stack-induced depressurization at floor level, resulting in higher radon concentrations in the building zones as the temperature difference increases. 
Tables 37 and 38 show the results at temperature differences of 0 and $30^{\circ} \mathrm{C}$ as a function of wind speed with the fans off and wind from the north. As seen in Table 37, radon from the soil enters the building at wind speeds greater than zero. Almost all of the occupied zones are depressurized. Non-zero wind speeds induce building depressurization, pulling soil gas into the building and increasing radon entry rates and indoor radon concentrations. As shown in Table 38 , radon enters the building at all wind speeds at a temperature difference of $30^{\circ} \mathrm{C}$ and the entry rate increases with wind speed. As the wind speed increases, the air change rate increases at a lower rate than the radon entry rate. Therefore, the building average radon concentration decreases at first and then starts to increase at $8 \mathrm{~m} / \mathrm{s}$.

\section{DISCUSSION}

Four large buildings were idealized as multi-zone airflow systems to examine the effects of indoor-outdoor temperature difference, wind speed and direction, and ventilation system operation on building airflow rates, interzone airflow patterns and radon concentrations. The input values used in these simulations are based on the limited data available in the literature, design ventilation rates for the three mechanically-ventilated buildings, and many assumptions. The numerical results of these simulations should not be generalized to specific buildings or the building stock in general. However, the results for different cases can be compared to evaluate the impacts of building, system and weather parameters. As seen in the results section of this report, airflow in multizone buildings is complex and the ability to intuitively explain the impact of the parameters studied in these simulations is often limited. However, some general patterns were observed, and these observations are discussed in this section.

The predictions in the twelve-story apartment building reveal the impact of the stack effect on airflow, radon entry and radon transport in tall buildings with vertical shafts. These results show that a negative indoor-outdoor temperature difference (i.e., colder inside than outside) tends to inhibit radon entry due to the positive pressurization of the lower building floors. A positive temperature difference will induce radon entry due to the depressurization of the lower floors. If the radon entry rate is pressure dependent, then a larger value of the temperature difference will result in a larger rate of radon entry. The impact of an increased radon entry rate on indoor radon concentrations depends on how rapidly the building air change rate increases with temperature difference. If the outdoor air change rate increases with temperature at a lower rate relative to the increase in the radon entry rate, then the indoor radon concentrations will increase with temperature difference. If the air change rate increase is faster than the increase in radon entry, then the concentrations will decrease. The dependence of the building air change rate on temperature is a function of many factors including building height, internal resistance to vertical airflow and ventilation system operation. In any given building, multi-zone airflow modeling, or measurement, must be used to determine whether the increase in the radon entry rate or the increase in the building air change rate will dominate.

When there are vertical shafts in a building, the stack effect will cause air to flow into the shafts on the lower floors and out of the shafts on the upper floors when the indoor-outdoor temperature difference is positive. The depressurization of the lower floors will draw radon into the building, if there is a source in the soil. This interior airflow pattern will generally lead to 
little or no radon reaching the lower floors of the building, except those floors in contact with the soil. Radon will reach the upper floors to which air is flowing from the building shafts. Higher floors will have more airflow from the shafts and higher radon concentrations, assuming they have the same rate of outdoor air dilution. The effect of vertical shafts on airflow and radon transport is evident in the results of the apartment building simulations.

The simulations in all of the buildings showed that when there is no mechanical ventilation, wind will tend to depressurize the building and draw radon in from the soil. The amount of the depressurization will increase with wind speed, and if the radon source is pressure dependent then the radon entry rate will also increase. Whether or not the radon concentrations in the building increase depends on whether the radon entry rate or the outdoor air change rate increases more rapidly with wind speed. The magnitude of the wind-induced depressurization varies with wind direction based on the dependence of surface wind pressure coefficients on direction. The values of wind pressure coefficients depend on wind direction, location on the building facade, the orientation of the building, the surrounding terrain and the presence of obstructions in the immediate vicinity of the building. In addition, the distribution of air leakage sites over the exterior envelope of the building impacts the dependence of wind-induced depressurization on wind direction. Therefore, the depressurization of a building and its groundcontact floors can be a strong function of wind direction. Wind direction can also impact interzone airflow patterns within a building, thereby affecting the transport of radon within a building and the concentrations in individual zones.

In general the wind and stack effects act together, and the results of this interaction are more involved than either acting alone. For example, if the temperature difference is negative, then the ground-contact floor (often the basement) will tend to be pressurized at low wind speed and no radon will enter the building. However, as the wind speed increases, the building tends to become depressurized, and this effect works against the pressurization of the lower floors by the stack effect. At some value of wind speed, the wind-induced depressurization will overcome the stack-induced pressurization of the ground-contact floor, and radon will enter the building. Wind-induced depressurization can also overcome the stack-induced airflow from lower floors into vertical shafts and prevent ground-source radon from entering these floors. At high enough wind speeds, these lower floors of the building will become sufficiently depressurized such that radon will enter the floors from the vertical shafts and from ground-contact floors.

Mechanical ventilation system airflows further complicate building airflow patterns and radon transport making the simulation results harder to explain intuitively. The existence of exhaust ventilation, at zero wind speed, will tend to depressurize a building and the groundcontact floors. This system-induced depressurization will tend to increase radon entry rates as the exhaust airflow rate increases, when the radon source strength is pressure dependent. If the exhaust airflow rates are large enough, the induced depressurization can counteract the stackinduced pressurization of the ground-contact floors when the temperature difference is negative. While exhaust ventilation increases radon entry rates, it will generally result in lower indoor radon concentrations because outdoor air dilution rates are also increased by the exhaust ventilation. However, radon concentrations in ground-contact zones are more likely to increase with exhaust ventilation, depending on the extent of their leakiness to the outdoors. 
The impact of mechanical ventilation when there is both outdoor air intake and exhaust is more complicated and depends on the distribution of the ventilation air in the building, the configuration of the building zones and weather conditions. In general, the net pressure effect in a given zone depends on the relative amounts of outdoor air intake into the zone and exhaust airflow out. The pressure effect on a zone can also be considered in terms of the amounts of supply airflow to the zone compared to the return plus exhaust airflow out of the zone. The net balance of these airflow rates determines whether the zone will be pressurized or depressurized. However, one must also consider weather effects on the zone pressure and the system- and weather-induced pressure effects in adjoining zones. In a multi-zone building the interaction of these effects can be very complex, and the interzone patterns of airflow and radon transport become similarly complex and sometimes nonintuitive.

In general, when there is an excess of supply airflow relative to return plus exhaust airflow (or an excess of intake relative to exhaust), the building will tend to be pressurized, inhibiting radon entry. This pressurization can be overcome by the stack effect when there is a positive temperature difference or by the wind. The simulation results in both office buildings showed cases in which weather effects dominated over ventilation system pressurization. When there is less intake than exhaust, the building tends to become depressurized, increasing the rate of radon entry into the building. However, regardless of whether there is an excess of intake over exhaust or a deficit of intake, the resultant radon concentrations throughout the building depend on the interzone airflow patterns. These patterns are in turn a complex function of building configuration, airtightness and weather conditions. The simulations in the office buildings included cases in which an excess of exhaust resulted in lower radon concentrations in the occupied space due to complex interzone airflow patterns.

The simulations in Office Building No.1 revealed an interesting and unexpected interaction between mechanical ventilation and wind. With a positive supply of air (i.e., more supply airflow into the space than return airflow out) and the wind blowing into the corner of this square building, the building is depressurized at low wind speeds for a positive value of the indoor-outdoor temperature difference. In this case, the building pressure increases as the wind speed increases and eventually becomes positive at a sufficiently high value of wind speed. When there is no mechanical ventilation, increasing wind speed tends to increase the depressurization of a building, but due to the nonlinear characteristics of the airflow paths the building becomes less depressurized with wind when there is a positive air supply for this wind direction. When the wind direction changes such that it impinges on one of the building sides, the dependence of building pressure on wind changes dramatically. The building is depressurized at low wind speeds and then becomes less so as the wind speed increases. As the wind speed increases further, the depressurization of the building increases again. Plotting building pressure against wind speed, there is a maximum in the pressure at an intermediate value of wind speed. When there is no mechanical ventilation, the building pressure decreases with wind speed regardless of the wind direction. This interaction of mechanical ventilation and wind would not be expected based on physical intuition, and presumably other complex and nonintuitive interactions will be revealed in airflow simulations of multizone buildings. 


\section{REFERENCES}

Austin, B. S., S. M. Greenfield, B. R. Weir, G. E. Anderson, and J. V. Behar. 1992. "Modeling the Indoor Environment." Environmental Science and Technology, 26(5), 851-858.

Cohen, B. L., D. R. Kulwicki, K. R. Warner, and C. L. Grassi. 1984. "Radon Concentrations Inside Public and Commercial Buildings in the Pittsburgh Area." Health Physics, 47, 399-405.

Dols, W. S. and A. K. Persily. 1992. "A Study of Ventilation Measurement in an Office Building." NISTIR 4905, National Institute of Standards and Technology, Gaithersburg, MD.

Fang, J. B. and A. K. Persily. 1994. "CONTAM88 Building Input Files for Multi-Zone Airflow and Contaminant Dispersal Modeling." NISTIR 5440, National Institute of Standards and Technology, Gaithersburg, MD.

Feustel, H. E. and V. M. Kendon. 1985. "Infiltration Models for Multicellular Structures - A Literature Review." Energy and Buildings, 8, 123-136.

Feustel, H. E. and J. Dieris. 1992. "A Survey of Airflow Models for Multizone Structures." Energy and Buildings, 18, 79-100.

Gadgil, A. J. 1992. "Models of Radon Entry: A Review." Radiation Protection Dosimetry, 45 (1/4), 373-380.

Grot, R. A., A. K. Persily, A. T. Hodgson, and J. M. Daisey. 1989. "Environmental Evaluation of the Portland East Federal Office Building Preoccupancy and Early Occupancy Results." NISTIR 89-4066. National Institute of Standards and Technology, Gaithersburg, MD.

Grot, R. A. 1991. "User Manual NBSAVIS CONTAM88." NISTIR 4585, National Institute of Standards and Technology, Gaithersburg, MD.

Haghighat, F. 1989. "Air Infiltration and Indoor Air Quality Models - A Review." International Journal of Ambient Energy, 10(3), 115-122.

Persily, A. K., W. S. Dols, S. J. Nabinger, and S. Kirchner. 1991. "Preliminary Results of the Environmental Evaluation of the Federal Records Center in Overland Missouri." NISTIR 4634, National Institute of Standards and Technology, Gaithersburg, MD.

Persily, A. K., W. S. Dols, and S. J. Nabinger. 1992. "Environmental Evaluation of the Federal Records Center in Overland Missouri." NISTIR 4883, National Institute of Standards and Technology, Gaithersburg, MD.

Persily, A. K. 1993. "Modeling Radon Transport in Multi-Story Residential Buildings." Modeling of Indoor Air Quality and Exposure, ASTM STP 1205, Niren L. Nagda, Ed., American Society for Testing and Materials, Philadelphia, PA, 226-242. 
Revzan, K. L., W. J. Fisk, and A. J. Gadgil. 1991. "Modeling Radon Entry into Houses with Basements: Model Description and Verification." Indoor Air, 1(2), 173-189.

Said, N. A. 1988. "A Review of Smoke Control Models. " ASHRAE Journal, 30(4), 36-40.

Turk, B. H., J. T. Brown, K. Geisling-Sobotka, D. A. Froehlich, D. T. Grimsrud, J. Harrison, J. F. Koonce, R. J. Prill, and K. L. Revzan. 1987. "Indoor Air Quality and Ventilation Measurements in 38 Pacific Northwest Commercial Buildings." LBL-22315, Lawrence Berkeley Laboratory, Berkeley, CA. 


\section{ACKNOWLEDGEMENTS}

The authors acknowledge the U.S. Environmental Protection Agency, Office of Radiation and Indoor Air for their support of this project under Interagency Agreement Number DW1393577701-0. Special thanks go to Bryan Ligman of EPA for his continued interest in this project. The efforts of Lucy Poole of NIST in preparing this report are greatly appreciated. 
Table 1. Summary of Simulations

\section{APARTMENT BUILDING}

\section{Pressure Dependent Radon Source}

Wind speed $=0 \mathrm{~m} / \mathrm{s} ; \Delta \mathrm{T}=-10$ to $30^{\circ} \mathrm{C}$

Wind speed $=0$ to $10 \mathrm{~m} / \mathrm{s}$; direction $=$ north; $\Delta \mathrm{T}=-10$ to $30^{\circ} \mathrm{C}$

$47 \mathrm{~L} / \mathrm{s}$ exhaust fan in each apartment; wind speed $=0 \mathrm{~m} / \mathrm{s}$; direction $=$ north; $\Delta \mathrm{T}=-10$ to $30^{\circ} \mathrm{C}$

$47 \mathrm{~L} / \mathrm{s}$ exhaust fan in each apartment; wind speed $=0$ to $10 \mathrm{~m} / \mathrm{s}$; direction $=$ north; $\Delta \mathrm{T}=30^{\circ} \mathrm{C}$

Wind speed $=0$ to $10 \mathrm{~m} / \mathrm{s}$; direction $=90^{\circ} ; \Delta \mathrm{T}=-10$ to $30^{\circ} \mathrm{C}$

Pressure Independent Radon Source

Wind speed $=0 \mathrm{~m} / \mathrm{s} ; \Delta \mathrm{T}=-10$ to $30^{\circ} \mathrm{C}$

Wind speed $=0$ to $10 \mathrm{~m} / \mathrm{s}$; direction $=$ north; $\Delta \mathrm{T}=-10$ to $30^{\circ} \mathrm{C}$

OFFICE BUILDING NO. 1 (Pressure dependent radon source model)

Minimum outdoor air intake; wind speed $=0 \mathrm{~m} / \mathrm{s} ; \Delta \mathrm{T}=-10$ to $30{ }^{\circ} \mathrm{C}$

Minimum outdoor air intake; wind speed $=0$ to $10 \mathrm{~m} / \mathrm{s}$; direction $=$ north; $\Delta \mathrm{T}=-10$ to $30^{\circ} \mathrm{C}$

Minimum outdoor air intake; wind speed $=0$ to $10 \mathrm{~m} / \mathrm{s}$; direction $=45^{\circ} ; \Delta \mathrm{T}=-10$ to $30^{\circ} \mathrm{C}$

Fans off, $50 \%$ and $100 \%$ outdoor air intake; wind speed $=0$ to $10 \mathrm{~m} / \mathrm{s}$; direction $=$ north;

$$
\Delta \mathrm{T}=-10 \text { to } 30^{\circ} \mathrm{C}
$$

Fans off, $50 \%$ and $100 \%$ outdoor air intake; wind speed $=0$ to $10 \mathrm{~m} / \mathrm{s}$; direction $=45^{\circ}$;

$$
\Delta \mathrm{T}=-10 \text { to } 30^{\circ} \mathrm{C}
$$

Balanced supply and return airflow rates; minimum outdoor air intake; wind speed $=0$ to $10 \mathrm{~m} / \mathrm{s}$; direction $=$ north; $\Delta \mathrm{T}=-10$ to $30^{\circ} \mathrm{C}$

$10 \%$ deficit supply air; minimum outdoor air intake; wind speed $=0$ to $10 \mathrm{~m} / \mathrm{s}$; direction = north; $\Delta \mathrm{T}=-10$ to $30^{\circ} \mathrm{C}$

OFFICE BUILDING NO. 2 (Pressure dependent radon source model)

Minimum outdoor air intake; garage fans operating; wind speed $=0 \mathrm{~m} / \mathrm{s} ; \Delta \mathrm{T}=-10$ to $30{ }^{\circ} \mathrm{C}$

Minimum outdoor air intake; garage fans operating; wind speed $=0$ to $10 \mathrm{~m} / \mathrm{s}$; direction = north; $\Delta \mathrm{T}=-10$ to $30^{\circ} \mathrm{C}$

Minimum outdoor air intake; garage fans operating; wind speed $=0$ to $10 \mathrm{~m} / \mathrm{s}$; direction $=45^{\circ}$; $\Delta \mathrm{T}=-10$ to $30^{\circ} \mathrm{C}$

Fans off and $50 \%$ and $100 \%$ outdoor air intake with garage fans operating; wind speed $=0$ to 10 $\mathrm{m} / \mathrm{s}$; direction $=$ north; $\Delta \mathrm{T}=-10$ to $30{ }^{\circ} \mathrm{C}$

Fans off and $50 \%$ and $100 \%$ outdoor air intake with garage fans operating; wind speed $=0$ to 10 $\mathrm{m} / \mathrm{s}$; direction $=45^{\circ} ; \Delta \mathrm{T}=-10$ to $30^{\circ} \mathrm{C}$

SCHOOL BUILDING (Pressure dependent radon source model)

Outdoor air intake of $25 \%, 50 \%$ and $75 \%$; wind speed $=0 \mathrm{~m} / \mathrm{s} ; \Delta \mathrm{T}=30^{\circ} \mathrm{C}$

$50 \%$ Outdoor air intake; wind speed $=0$ and $10 \mathrm{~m} / \mathrm{s} ; \Delta \mathrm{T}=0$ and $30^{\circ} \mathrm{C}$

Fans off; wind speed $=0$ to $10 \mathrm{~m} / \mathrm{s}$; direction $=$ north; $\Delta \mathrm{T}=-10$ to $30^{\circ} \mathrm{C}$ 
Table 2. Simulation Results for Apartment Building, Wind speed $=0 \mathrm{~m} / \mathrm{s}$ (Pressure Dependent Radon Entry)

Radon Concentration, $\mathrm{Bq} / \mathrm{m}^{3}$

$\begin{array}{cccccccc}\begin{array}{c}\mathrm{T}_{\text {in }}-\mathrm{T}_{\text {out }}, \\ { }^{\circ} \mathrm{C}\end{array} & \begin{array}{c}\text { Building } \\ \text { Air Change } \\ \text { Rate, } \mathrm{h}^{-1}\end{array} & \begin{array}{c}\text { Basement } \\ \text { Pressure, } \\ \mathrm{Pa}\end{array} & \begin{array}{c}\text { Radon Entry } \\ \text { Rate, Bq/s }\end{array} & \text { Basement } & \begin{array}{c}\text { 2nd Floor } \\ \text { Apartments }\end{array} & \begin{array}{c}\text { 12th Floor } \\ \text { Apartments }\end{array} & \begin{array}{c}\text { Average } \\ \text { of All } \\ \text { Apartments }\end{array} \\ -10 & 0.10 & 4.5 & 0 & 10.3 & 10.3 & 10.3 & 10.3 \\ 0 & 0.0 & 0.0 & 0 & 10.0 & 10.0 & 10.0 & 10.0 \\ 10 & 0.10 & -4.8 & 69 & 874 & 9.7 & 141 & 63.9 \\ 20 & 0.16 & -9.8 & 140 & 1130 & 9.3 & 180 & 78.0 \\ 30 & 0.20 & -15.0 & 215 & 1320 & 9.0 & 209 & 89.9\end{array}$

Table 3. Simulation Results for Apartment Building, $\mathrm{T}_{\mathrm{in}}-\mathrm{T}_{\text {out }}=-10^{\circ} \mathrm{C}$ (Pressure Dependent Radon Entry)

Radon Concentration, $\mathrm{Bq} / \mathrm{m}^{3}$

$\begin{array}{cccccccc}\begin{array}{c}\text { Wind } \\ \text { Speed, } \\ \mathrm{m} / \mathrm{s}\end{array} & \begin{array}{c}\text { Building } \\ \text { Air Change } \\ \text { Rate, } \mathrm{h}^{-1}\end{array} & \begin{array}{c}\text { Basement } \\ \text { Pressure, } \\ \mathrm{Pa}\end{array} & \begin{array}{c}\text { Radon Entry } \\ \text { Rate, Bq/s }\end{array} & \text { Basement } & \begin{array}{c}\text { 2nd Floor } \\ \text { Apartments }\end{array} & \begin{array}{c}\text { 12th Floor } \\ \text { Apartments }\end{array} & \begin{array}{c}\text { Average } \\ \text { of All } \\ \text { Apartments }\end{array} \\ 0 & 0.10 & 4.5 & 0 & 10.3 & 10.3 & 10.3 & 10.3 \\ 2 & 0.16 & 4.3 & 0 & 10.3 & 10.3 & 10.3 & 10.3 \\ 4 & 0.31 & 3.3 & 0 & 10.3 & 10.3 & 10.3 & 10.3 \\ 6 & 0.49 & 1.3 & 0 & 10.3 & 10.3 & 10.3 & 10.3 \\ 8 & 0.69 & -1.4 & 21 & 235 & 11.1 & 10.3 & 11.8 \\ 10 & 0.90 & -5.1 & 73 & 705 & 12.2 & 10.3 & 14.5\end{array}$


Table 4. Simulation Results for Apartment Building, $\mathrm{T}_{\text {in }}-\mathrm{T}_{\text {out }}=0{ }^{\circ} \mathrm{C}$ (Pressure Dependent Radon Entry)

Radon Concentration, $\mathrm{Bq} / \mathrm{m}^{3}$

$\begin{array}{cccccccc}\begin{array}{c}\text { Wind } \\ \text { Speed, } \\ \mathrm{m} / \mathrm{s}\end{array} & \begin{array}{c}\text { Building } \\ \text { Air Change } \\ \text { Rate, } \mathrm{h}^{-1}\end{array} & \begin{array}{c}\text { Basement } \\ \text { Pressure, } \\ \mathrm{Pa}\end{array} & \begin{array}{c}\text { Radon Entry } \\ \text { Rate, } \mathrm{Bq} / \mathrm{s}\end{array} & \text { Basement } & \begin{array}{c}\text { 2nd Floor } \\ \text { Apartments }\end{array} & \begin{array}{c}\text { 12th Floor } \\ \text { Apartments }\end{array} & \begin{array}{c}\text { Average } \\ \text { of All } \\ \text { Apartments }\end{array} \\ 0 & 0.0 & 0.0 & 0 & 10.0 & 10.0 & 10.0 & 10.0 \\ 2 & 0.12 & -0.4 & 6 & 643 & 11.2 & 10.0 & 13.3 \\ 4 & 0.29 & -1.7 & 24 & 1020 & 12.3 & 10.0 & 14.8 \\ 6 & 0.48 & -3.8 & 54 & 1350 & 13.5 & 10.0 & 16.1 \\ 8 & 0.69 & -6.7 & 95 & 1650 & 14.7 & 10.0 & 17.5 \\ 10 & 0.90 & -10.4 & 149 & 1950 & 15.7 & 10.0 & 18.8\end{array}$

Table 5. Simulation Results for Apartment Building, $\mathrm{T}_{\text {in }}-\mathrm{T}_{\text {out }}=10^{\circ} \mathrm{C}$ (Pressure Dependent Radon Entry)

Radon Concentration, $\mathrm{Bq} / \mathrm{m}^{3}$

Wind Building Basement Radon Entry

Speed, Air Change Pressure, Rate, $\mathrm{Bq} / \mathrm{s}$

$\mathrm{m} / \mathrm{s} \quad$ Rate, $\mathrm{h}^{-1}$

0

2

4

6

8

10
0.10

0.15

0.30

0.48

0.68

0.89
$\mathrm{Pa}$

$-4.8$

$-5.1$

$-6.6$

$-9.2$

$-12.3$

$-16.1$
Basement

2nd Floo

Apartment

69

74

95

132

176

231

874

979

1530

3040

2970

2920
9.7

9.7

9.7

9.7

15.0

30.4 12th Floor

Apartments
Average of All Apartments

63.9

52.7

51.0

45.6

35.9

33.3 
Table 6. Simulation Results for Apartment Building with Exhaust Fans, Wind speed $=0 \mathrm{~m} / \mathrm{s}$ (Pressure Dependent Radon Entry)

Radon Concentration, $\mathrm{Bq} / \mathrm{m}^{3}$

$\begin{array}{cccccccc}\begin{array}{c}\mathrm{T}_{\text {in }}-\mathrm{T}_{\text {out }} \\ { }^{\circ} \mathrm{C}\end{array} & \begin{array}{c}\text { Building } \\ \text { Air Change } \\ \text { Rate, } \mathrm{h}^{-1}\end{array} & \begin{array}{c}\text { Basement } \\ \text { Pressure, } \\ \mathrm{Pa}\end{array} & \begin{array}{c}\text { Radon Entry } \\ \text { Rate, Bq/s }\end{array} & \text { Basement } & \begin{array}{c}\text { 2nd Floor } \\ \text { Apartments }\end{array} & \begin{array}{c}\text { 12th Floor } \\ \text { Apartments }\end{array} & \begin{array}{c}\text { Average } \\ \text { of All } \\ \text { Apartments }\end{array} \\ -10 & 0.39 & 3.4 & 0 & 10.3 & 10.3 & 10.3 & 10.3 \\ 0 & 0.36 & -1.1 & 15 & 804 & 10.0 & 10.0 & 17.1 \\ 10 & 0.36 & -6.0 & 87 & 1070 & 9.66 & 116 & 42.7 \\ 20 & 0.38 & -11.2 & 160 & 1280 & 9.32 & 164 & 61.2 \\ 30 & 0.41 & -16.6 & 238 & 1440 & 8.99 & 196 & 74.2\end{array}$

Table 7. Simulation Results for Apartment Building with Pressure Independent Radon Source, Wind Speed $=0 \mathrm{~m} / \mathrm{s}$

Radon Concentration, $\mathrm{Bq} / \mathrm{m}^{3}$

$\begin{array}{cccccccc}\begin{array}{c}\mathrm{T}_{\text {in }}-\mathrm{T}_{\text {out, }} \\ { }^{\circ} \mathrm{C}\end{array} & \begin{array}{c}\text { Building } \\ \text { Air Change } \\ \text { Rate, } \mathrm{h}^{-1}\end{array} & \begin{array}{c}\text { Basement } \\ \text { Pressure, } \\ \mathrm{Pa}\end{array} & \begin{array}{c}\text { Radon Entry } \\ \text { Rate, Bq/s }\end{array} & \text { Basement } & \begin{array}{c}\text { 2nd Floor } \\ \text { Apartments }\end{array} & \begin{array}{c}\text { 12th Floor } \\ \text { Apartments }\end{array} & \begin{array}{c}\text { Average } \\ \text { of All } \\ \text { Apartments }\end{array} \\ -10 & 0.10 & 4.5 & 0 & 10.3 & 10.3 & 10.3 & 10.3 \\ 0 & 0.0 & 0 & 0 & 10.0 & 10.0 & 10.0 & 10.0 \\ 10 & 0.10 & -4.8 & 36 & 461 & 9.7 & 78.0 & 37.8 \\ 20 & 0.16 & -9.8 & 36 & 296 & 9.3 & 52.8 & 27.0 \\ 30 & 0.20 & -15.0 & 36 & 226 & 9.0 & 42.1 & 22.4\end{array}$


Table 8. Simulation Results for Apartment Building with Pressure Independent Radon Source, $T_{\text {in }}-T_{\text {out }}=-10{ }^{\circ} \mathrm{C}$ Radon Concentration, $\mathrm{Bq} / \mathrm{m}^{3}$

$\begin{array}{cccccccc}\begin{array}{c}\text { Wind } \\ \text { Speed, } \\ \mathrm{m} / \mathrm{s}\end{array} & \begin{array}{c}\text { Building } \\ \text { Air Change } \\ \text { Rate, } \mathrm{h}^{-1}\end{array} & \begin{array}{c}\text { Basement } \\ \text { Pressure, } \\ \mathrm{Pa}\end{array} & \begin{array}{c}\text { Radon Entry } \\ \text { Rate, Bq/s }\end{array} & \text { Basement } & \begin{array}{c}\text { 2nd Floor } \\ \text { Apartments }\end{array} & \begin{array}{c}\text { 12th Floor } \\ \text { Apartments }\end{array} & \begin{array}{c}\text { Average } \\ \text { of All } \\ \text { Apartments }\end{array} \\ 0 & 0.10 & 4.5 & 0 & 10.3 & 10.3 & 10.3 & 10.3 \\ 2 & 0.16 & 4.3 & 0 & 10.3 & 10.3 & 10.3 & 10.3 \\ 4 & 0.31 & 3.3 & 0 & 10.3 & 10.3 & 10.3 & 10.3 \\ 6 & 0.49 & 1.3 & 0 & 10.3 & 10.3 & 10.3 & 10.3 \\ 8 & 0.69 & -1.4 & 36 & 401 & 11.6 & 10.3 & 12.8 \\ 10 & 0.90 & -5.1 & 36 & 354 & 11.3 & 10.3 & 12.4\end{array}$

Table 9. Simulation Results for Apartment Building with Pressure Independent Radon Source, $\mathrm{T}_{\text {in }}-\mathrm{T}_{\text {out }}=0{ }^{\circ} \mathrm{C}$ Radon Concentration, $\mathrm{Bq} / \mathrm{m}^{3}$

$\begin{array}{cccccccc}\begin{array}{c}\text { Wind } \\ \text { Speed, } \\ \mathrm{m} / \mathrm{s}\end{array} & \begin{array}{c}\text { Building } \\ \text { Air Change } \\ \text { Rate, } \mathrm{h}^{-1}\end{array} & \begin{array}{c}\text { Basement } \\ \text { Pressure, } \\ \mathrm{Pa}\end{array} & \begin{array}{c}\text { Radon Entry } \\ \text { Rate, Bq/s }\end{array} & \text { Basement } & \begin{array}{c}\text { 2nd Floor } \\ \text { Apartments }\end{array} & \begin{array}{c}\text { 12th Floor } \\ \text { Apartments }\end{array} & \begin{array}{c}\text { Average } \\ \text { of All } \\ \text { Apartments }\end{array} \\ 0 & 0.0 & 0.0 & 0 & 10 & 10.0 & 10.0 & 10.0 \\ 2 & 0.12 & -0.4 & 36 & 4110 & 18.0 & 10.0 & 31.2 \\ 4 & 0.29 & -1.7 & 36 & 1530 & 13.4 & 10.0 & 17.1 \\ 6 & 0.48 & -3.7 & 36 & 904 & 12.4 & 10.0 & 14.1 \\ 8 & 0.69 & -6.7 & 36 & 627 & 11.8 & 10.0 & 12.8 \\ 10 & 0.90 & -10.4 & 36 & 477 & 11.4 & 10.0 & 12.1\end{array}$


Table 10. Simulation Results for Apartment Building with Pressure Independent Radon Source, $T_{\text {in }}-T_{\text {out }}=10^{\circ} \mathrm{C}$ Radon Concentration, $\mathrm{Bq} / \mathrm{m}^{3}$

$\begin{array}{cccccccc}\begin{array}{c}\text { Wind } \\ \text { Speed, } \\ \mathrm{m} / \mathrm{s}\end{array} & \begin{array}{c}\text { Building } \\ \text { Air Change } \\ \text { Rate, } \mathrm{h}^{-1}\end{array} & \begin{array}{c}\text { Basement } \\ \text { Pressure, } \\ \mathrm{Pa}\end{array} & \begin{array}{c}\text { Radon Entry } \\ \text { Rate, Bq/s }\end{array} & \text { Basement } & \begin{array}{c}\text { 2nd Floor } \\ \text { Apartments }\end{array} & \begin{array}{c}\text { 12th Floor } \\ \text { Apartments }\end{array} & \begin{array}{c}\text { Average } \\ \text { of All } \\ \text { Apartments }\end{array} \\ 0 & 0.10 & -4.8 & 36 & 461 & 9.7 & 78.0 & 37.8 \\ 2 & 0.15 & -5.1 & 36 & 482 & 9.7 & 63.3 & 30.6 \\ 4 & 0.30 & -6.6 & 36 & 587 & 9.7 & 46.6 & 25.3 \\ 6 & 0.48 & -9.2 & 36 & 833 & 9.7 & 31.9 & 19.4 \\ 8 & 0.68 & -12.3 & 36 & 612 & 10.8 & 16.5 & 15.0 \\ 10 & 0.89 & -16.1 & 36 & 461 & 12.9 & 11.1 & 13.3\end{array}$

Table 11. Simulation Results for Apartment Building, Wind $90^{\circ}$ from the North, $T_{\text {in }}-T_{\text {out }}=0{ }^{\circ} \mathrm{C}$ (Pressure Dependent Radon Entry)

Radon Concentration, $\mathrm{Bq} / \mathrm{m}^{3}$

$\begin{array}{cccccccc}\begin{array}{c}\text { Wind } \\ \text { Speed, } \\ \mathrm{m} / \mathrm{s}\end{array} & \begin{array}{c}\text { Building } \\ \text { Air Change } \\ \text { Rate, } \mathrm{h}^{-1}\end{array} & \begin{array}{c}\text { Basement } \\ \text { Pressure, } \\ \mathrm{Pa}\end{array} & \begin{array}{c}\text { Radon Entry } \\ \text { Rate, Bq/s }\end{array} & \text { Basement } & \begin{array}{c}\text { 2nd Floor } \\ \text { Apartments }\end{array} & \begin{array}{c}\text { 12th Floor } \\ \text { Apartments }\end{array} & \begin{array}{c}\text { Average } \\ \text { of All } \\ \text { Apartments }\end{array} \\ 0 & 0.0 & 0.0 & 0 & 10 & 10.0 & 10.0 & 10.0 \\ 2 & 0.13 & 0.0 & 0 & 10 & 10.0 & 10.0 & 10.0 \\ 4 & 0.30 & -0.3 & 4 & 105 & 13.5 & 10.0 & 10.3 \\ 6 & 0.48 & -0.7 & 11 & 153 & 15.3 & 10.0 & 10.5 \\ 8 & 0.68 & -1.3 & 19 & 196 & 16.9 & 10.0 & 10.7 \\ 10 & 0.89 & -2.1 & 31 & 235 & 18.3 & 10.0 & 10.8\end{array}$


Table 12. Simulation Results for Apartment Building, Wind $90^{\circ}$ from the North, $T_{\text {in }}-T_{\text {out }}=0{ }^{\circ} \mathrm{C}$ (Pressure Dependent Radon Entry)

$\begin{array}{cccccccc}\begin{array}{r}\text { Wind } \\ \begin{array}{c}\text { Speed, } \\ \text { m/s }\end{array}\end{array} & \begin{array}{c}\text { Building } \\ \text { Air Change } \\ \text { Rate, } \mathrm{h}^{-1}\end{array} & \begin{array}{c}\text { Basement } \\ \text { Pressure, } \\ \mathrm{Pa}\end{array} & \begin{array}{c}\text { Radon Entry } \\ \text { Rate, Bq/s }\end{array} & \text { Basement } & \begin{array}{c}\text { Radon Concentration, Bq } / \mathrm{m}^{3} \\ \text { 2nd Foor } \\ \text { Apartments }\end{array} & \begin{array}{c}\text { 12th Floor } \\ \text { Apartments }\end{array} & \begin{array}{c}\text { Average } \\ \text { of All } \\ \text { Apartments }\end{array} \\ 0 & 0.10 & -4.8 & 69 & 874 & 9.7 & 141 & 63.9 \\ 2 & 0.16 & -4.7 & 68 & 857 & 9.7 & 122 & 48.1 \\ 4 & 0.32 & -5.0 & 71 & 919 & 9.7 & 70.7 & 32.2 \\ 6 & 0.50 & -5.8 & 83 & 903 & 21.9 & 35.7 & 24.8 \\ 8 & 0.69 & -6.7 & 96 & 797 & 39.8 & 15.3 & 19.4 \\ 10 & 0.90 & -7.5 & 107 & 710 & 44.4 & 9.9 & 15.5\end{array}$

Table 13. Simulation Results for Office Building No. 1, Wind speed $=0 \mathrm{~m} / \mathrm{s}$, Minimum Outdoor Air

Radon Concentration, $\mathrm{Bq} / \mathrm{m}^{3}$

$\mathrm{T}_{\text {in }}-\mathrm{T}_{\text {out }}$ Building Basement Radon Entry Basement 1st Floor 5th Floor

${ }^{\circ} \mathrm{C}$ Air Change Pressure, Rate, $\mathrm{Bq} / \mathrm{s}$ Rate, $\mathrm{h}^{-1} \quad \mathrm{~Pa}$

$-10$

0.71

8.0

0

10.3

$1.7 \quad 0$

10.0

10.3

10.3

10.0

10.0

Average

of All

Floors

0

0.67

$-4.1$

369

209

9.7

14.4

500

9.3

21.6

10.3

20

0.66

$-10.1$

921

811

9.0

30.0

10.0

39.4

82.5

$\begin{array}{ll}-16.8 & 1525\end{array}$

129 
Table 14. Simulation Results for Office Building No. $1, \mathrm{~T}_{\text {in }}-\mathrm{T}_{\text {out }}=10^{\circ} \mathrm{C}$, Minimum Outdoor Air Radon Concentration, $\mathrm{Bq} / \mathrm{m}^{3}$ Wind Building Basement Radon Entry Basement 1st Floor 5th Floor Speed, Air Change Pressure, Rate, Bq/s

$\begin{array}{cccccccc}\mathrm{m} / \mathrm{s} & \text { Rate, } \mathrm{h}^{-1} & \mathrm{~Pa} & & & & \text { Floors } \\ 0 & 0.66 & -4.1 & 369 & 209 & 9.7 & 14.4 & 39.4 \\ 2 & 0.66 & -4.0 & 368 & 209 & 9.7 & 14.4 & 39.4 \\ 4 & 0.68 & -3.5 & 322 & 185 & 9.8 & 13.5 & 35.7 \\ 6 & 0.72 & -2.3 & 212 & 125 & 9.8 & 11.7 & 26.7 \\ 8 & 0.77 & -1.3 & 116 & 73.7 & 9.7 & 10.5 & 19.0 \\ 10 & 0.83 & -0.4 & 34 & 28.2 & 9.7 & 9.9 & 12.4\end{array}$

Table 15. Simulation Results for Office Building No. 1, Fans Off, $T_{\text {in }}-T_{\text {out }}=0{ }^{\circ} \mathrm{C}$, Wind from the North Radon Concentration, $\mathrm{Bq} / \mathrm{m}^{3}$

$\begin{array}{cccccccc}\begin{array}{c}\text { Wind } \\ \text { Speed, } \\ \mathrm{m} / \mathrm{s}\end{array} & \begin{array}{c}\text { Building } \\ \text { Air Change } \\ \text { Rate, } \mathrm{h}^{-1}\end{array} & \begin{array}{c}\text { Basement } \\ \text { Pressure, } \\ \mathrm{Pa}\end{array} & \begin{array}{c}\text { Radon Entry } \\ \text { Rate, } \mathrm{Bq} / \mathrm{s}\end{array} & \text { Basement } & \text { 1st Floor } & \text { 5th Floor } & \begin{array}{c}\text { Average } \\ \text { of All } \\ 0\end{array} \\ 0.0 & 0.0 & 0.0 & 10 & 10.0 & 10 & \begin{array}{c}\text { Floors } \\ 2\end{array} \\ 0.03 & 0.0 & 0.9 & 204 & 10.1 & 10 & 39.8 \\ 4 & 0.07 & 0.0 & 3.6 & 298 & 10.2 & 10 & 53.8 \\ 6 & 0.12 & -0.1 & 8.2 & 407 & 10.2 & 10 & 70.3 \\ 8 & 0.17 & -0.2 & 14 & 509 & 10.3 & 10 & 85.8 \\ 10 & 0.22 & -0.3 & 23 & 606 & 10.3 & 10 & 101\end{array}$


Table 16. Simulation Results for Office Building No. 1, Fans Off, $\mathrm{T}_{\mathrm{in}}-\mathrm{T}_{\text {out }}=10^{\circ} \mathrm{C}$, Wind from the North

Radon Concentration, $\mathrm{Bq} / \mathrm{m}^{3}$

$\begin{array}{cccccccc}\begin{array}{c}\text { Wind } \\ \text { Speed, } \\ \mathrm{m} / \mathrm{s}\end{array} & \begin{array}{c}\text { Building } \\ \text { Air Change } \\ \text { Rate, } \mathrm{h}^{-1}\end{array} & \begin{array}{c}\text { Basement } \\ \text { Pressure, } \\ \mathrm{Pa}\end{array} & \begin{array}{c}\text { Radon Entry } \\ \text { Rate, Bq/s }\end{array} & \text { Basement } & \text { 1st Floor } & \text { 5th Floor } & \begin{array}{c}\text { Average } \\ \text { of All } \\ \text { Floors }\end{array} \\ 0 & 0.05 & -6.2 & 560 & 11700 & 9.7 & 382 & 1771 \\ 2 & 0.05 & -6.2 & 560 & 11700 & 9.7 & 379 & 1768 \\ 4 & 0.07 & -6.2 & 560 & 11400 & 9.7 & 311 & 1699 \\ 6 & 0.12 & -6.3 & 570 & 11600 & 9.7 & 157 & 1696 \\ 8 & 0.17 & -6.3 & 574 & 10900 & 9.7 & 96 & 1584 \\ 10 & 0.22 & -6.3 & 577 & 10000 & 9.7 & 65 & 1448\end{array}$

Table 17. Simulation Results for Office Building No. $1,50 \%$ Outdoor Air Intake, $\mathrm{T}_{\text {in }}-\mathrm{T}_{\text {out }}=10^{\circ} \mathrm{C}$, Wind from the North

Radon Concentration, $\mathrm{Bq} / \mathrm{m}^{3}$

Wind Building Basement Radon Entry Basement 1st Floor 5th Floor Speed, Air Change Pressure, Rate, $\mathrm{Bq} / \mathrm{s}$

$\mathrm{m} / \mathrm{s} \quad$ Rate, $\mathrm{h}^{-1} \quad \mathrm{~Pa}$

$\begin{array}{cccccccc}0 & 1.72 & -4.0 & 369 & 65.7 & 9.7 & 10.6 & 17.9 \\ 2 & 1.72 & -4.0 & 368 & 65.6 & 9.7 & 10.6 & 17.9 \\ 4 & 1.74 & -3.5 & 322 & 58.7 & 9.7 & 10.4 & 16.9 \\ 6 & 1.78 & -2.3 & 212 & 42.0 & 9.7 & 10.1 & 14.4 \\ 8 & 1.84 & -1.3 & 117 & 27.5 & 9.7 & 9.8 & 12.3 \\ 10 & 1.89 & -0.4 & 34 & 14.9 & 9.7 & 9.7 & 10.4\end{array}$


Table 18. Simulation Results for Office Building No. $1,100 \%$ Outdoor Air Intake, $T_{\text {in }}-T_{\text {out }}=10{ }^{\circ} \mathrm{C}$, Wind from the North

\section{Radon Concentration, $\mathrm{Bq} / \mathrm{m}^{3}$}

$\begin{array}{cccccccc}\begin{array}{c}\text { Wind } \\ \text { Speed, } \\ \mathrm{m} / \mathrm{s}\end{array} & \begin{array}{c}\text { Building } \\ \text { Air Change } \\ \text { Rate, } \mathrm{h}^{-1}\end{array} & \begin{array}{c}\text { Basement } \\ \text { Pressure, } \\ \text { Pa }\end{array} & \begin{array}{c}\text { Radon Entry } \\ \text { Rate, Bq/s }\end{array} & \text { Basement } & \text { 1st Floor } & \text { 5th Floor } & \begin{array}{c}\text { Average } \\ \text { of All } \\ \text { Floors }\end{array} \\ 0 & 3.44 & -4.1 & 369 & 38.0 & 9.7 & 10.0 & 13.8 \\ 2 & 3.44 & -4.0 & 368 & 37.9 & 9.7 & 10.0 & 13.8 \\ 4 & 3.46 & -3.5 & 322 & 34.4 & 9.7 & 9.9 & 13.3 \\ 6 & 3.50 & -2.3 & 212 & 26.0 & 9.7 & 9.8 & 12.0 \\ 8 & 3.55 & -1.3 & 117 & 18.6 & 9.7 & 9.7 & 11.0 \\ 10 & 3.60 & -0.4 & 34 & 12.3 & 9.7 & 9.7 & 10.0\end{array}$

Table 19. Simulation Results for Office Building No. 1, Fans Off, $T_{\text {in }}-T_{\text {out }}=10^{\circ} \mathrm{C}$, Wind $45^{\circ}$ from the North Radon Concentration, $\mathrm{Bq} / \mathrm{m}^{3}$

$\begin{array}{cccccccc}\begin{array}{c}\text { Wind } \\ \text { Speed, } \\ \mathrm{m} / \mathrm{s}\end{array} & \begin{array}{c}\text { Building } \\ \text { Air Change } \\ \text { Rate, } \mathrm{h}^{-1}\end{array} & \begin{array}{c}\text { Basement } \\ \text { Pressure, } \\ \mathrm{Pa}\end{array} & \begin{array}{c}\text { Radon Entry } \\ \text { Rate, Bq/s }\end{array} & \text { Basement } & \text { 1st Floor } & \text { 5th Floor } & \begin{array}{c}\text { Average } \\ \text { of All } \\ \text { Floors }\end{array} \\ 0 & 0.05 & -6.2 & 560 & 11700 & 9.7 & 382 & 1771 \\ 2 & 0.05 & -6.2 & 562 & 11000 & 9.7 & 357 & 1661 \\ 4 & 0.09 & -7.0 & 636 & 11400 & 9.7 & 251 & 1691 \\ 6 & 0.14 & -8.6 & 779 & 12600 & 9.7 & 160 & 1841 \\ 8 & 0.19 & -10.7 & 970 & 13800 & 9.7 & 117 & 2004 \\ 10 & 0.25 & -13.4 & 1219 & 15400 & 9.7 & 105 & 229\end{array}$


Table 20. Simulation Results for Office Building No. 1, Minimum Outdoor Air Intake, $T_{\text {in }}-T_{\text {out }}=10^{\circ} \mathrm{C}$, Wind $45^{\circ}$ from the North

Radon Concentration, $\mathrm{Bq} / \mathrm{m}^{3}$

Wind Building Basement Radon Entry Basement 1st Floor 5th Floor Speed, Air Change Pressure, Rate, $\mathrm{Bq} / \mathrm{s}$

$\mathrm{m} / \mathrm{s} \quad$ Rate, $\mathrm{h}^{-1} \quad \mathrm{~Pa}$

$\begin{array}{ccccc}0 & 0.66 & -4.1 & 369 & 209 \\ 2 & 0.67 & -4.0 & 361 & 205 \\ 4 & 0.72 & -3.8 & 343 & 197 \\ 6 & 0.77 & -4.4 & 399 & 226 \\ 8 & 0.83 & -5.6 & 512 & 285 \\ 10 & 0.89 & -7.5 & 681 & 373\end{array}$

209
205
197
226
285
373

209

9.7

14.4

$9.7 \quad 14.2$

12.8

12.6

12.9

10.0

13.6
Average

of All

Floors

39.4

38.7

37.3

41.4

49.9

62.7

Table 21. Simulation Results for Office Building No. 1, 50\% Outdoor Air Intake, $\mathrm{T}_{\text {in }}-\mathrm{T}_{\text {out }}=10^{\circ} \mathrm{C}$, Wind $45^{\circ}$ from the North

Radon Concentration, $\mathrm{Bq} / \mathrm{m}^{3}$

$\begin{array}{cccccccc}\begin{array}{c}\text { Wind } \\ \text { Speed, } \\ \mathrm{m} / \mathrm{s}\end{array} & \begin{array}{c}\text { Building } \\ \text { Air Change } \\ \text { Rate, } \mathrm{h}^{-1}\end{array} & \begin{array}{c}\text { Basement } \\ \text { Pressure, } \\ \text { Pa }\end{array} & \begin{array}{c}\text { Radon Entry } \\ \text { Rate, Bq/s }\end{array} & \text { Basement } & \text { 1st Floor } & \text { 5th Floor } & \begin{array}{c}\text { Average } \\ \text { of All } \\ \text { Floors }\end{array} \\ 0 & 1.72 & -4.1 & 369 & 65.7 & 9.7 & 10.6 & 17.9 \\ 2 & 1.73 & -4.0 & 361 & 64.6 & 9.7 & 10.5 & 17.7 \\ 4 & 1.78 & -3.8 & 343 & 62.0 & 9.7 & 10.2 & 17.3 \\ 6 & 1.83 & -4.4 & 399 & 70.5 & 9.7 & 10.2 & 18.5 \\ 8 & 1.89 & -5.6 & 513 & 87.6 & 9.7 & 10.3 & 21.0 \\ 10 & 1.95 & -7.5 & 681 & 113 & 9.7 & 10.4 & 24.6\end{array}$


Table 22. Simulation Results for Office Building No. $1,100 \%$ Outdoor Air Intake, $\mathrm{T}_{\text {in }}-\mathrm{T}_{\text {out }}=10^{\circ} \mathrm{C}$, Wind $45^{\circ}$ from the North

Radon Concentration, $\mathrm{Bq} / \mathrm{m}^{3}$

$\begin{array}{cccccccc}\begin{array}{c}\text { Wind } \\ \begin{array}{c}\text { Speed, } \\ \mathrm{m} / \mathrm{s}\end{array}\end{array} & \begin{array}{c}\text { Building } \\ \text { Air Change } \\ \text { Rate, } \mathrm{h}^{-1}\end{array} & \begin{array}{c}\text { Basement } \\ \text { Pressure, } \\ \mathrm{Pa}\end{array} & \begin{array}{c}\text { Radon Entry } \\ \text { Rate, Bq/s }\end{array} & \text { Basement } & \text { 1st Floor } & \text { 5th Floor } & \begin{array}{c}\text { Average } \\ \text { of All } \\ \text { Floors }\end{array} \\ 0 & 3.44 & -4.1 & 369 & 38.0 & 9.7 & 10.0 & 13.8 \\ 2 & 3.44 & -4.0 & 361 & 37.4 & 9.7 & 10.0 & 13.7 \\ 4 & 3.49 & -3.8 & 343 & 36.1 & 9.7 & 9.9 & 13.5 \\ 6 & 3.55 & -4.4 & 399 & 40.4 & 9.7 & 9.9 & 14.1 \\ 8 & 3.60 & -5.6 & 513 & 49.1 & 9.7 & 9.9 & 15.3 \\ 10 & 3.66 & -7.5 & 681 & 62.0 & 9.7 & 9.9 & 17.2\end{array}$

Table 23. Simulation Results for Office Building No. 1, Balanced Supply and Return, Minimum Outdoor Air Intake, $\mathrm{T}_{\text {in }}-\mathrm{T}_{\text {out }}=10^{\circ} \mathrm{C}$, Wind from the North

Radon Concentration, $\mathrm{Bq} / \mathrm{m}^{3}$

$\begin{array}{cccccccc}\begin{array}{c}\text { Wind } \\ \text { Speed, } \\ \mathrm{m} / \mathrm{s}\end{array} & \begin{array}{c}\text { Building } \\ \text { Air Change } \\ \text { Rate, } \mathrm{h}^{-1}\end{array} & \begin{array}{c}\text { Basement } \\ \text { Pressure, } \\ \text { Pa }\end{array} & \begin{array}{c}\text { Radon Entry } \\ \text { Rate, Bq/s }\end{array} & \text { Basement } & \text { 1st Floor } & \text { 5th Floor } & \begin{array}{c}\text { Average } \\ \text { of All } \\ \text { Floors }\end{array} \\ 0 & 0.90 & -16.6 & 1513 & 540 & 9.7 & 9.7 & 85.4 \\ 2 & 0.90 & -16.6 & 1515 & 541 & 9.7 & 9.7 & 85.6 \\ 4 & 0.90 & -16.9 & 1539 & 550 & 9.7 & 9.7 & 86.9 \\ 6 & 0.90 & -18.1 & 1652 & 589 & 9.7 & 9.7 & 92.4 \\ 8 & 0.93 & -20.6 & 1873 & 668 & 9.7 & 9.7 & 104 \\ 10 & 0.97 & -23.6 & 2153 & 766 & 9.7 & 9.7 & 118\end{array}$


Table 24. Simulation Results for Office Building No. 1, 10\% Supply Deficit, Minimum Outdoor Air Intake, $\mathrm{T}_{\text {in }}-\mathrm{T}_{\text {out }}=10^{\circ} \mathrm{C}$, Wind from the North

Radon Concentration, $\mathrm{Bq} / \mathrm{m}^{3}$

Wind Building Basement Radon Entry Basement 1st Floor 5th Floor Speed, Air Change Pressure, Rate, $\mathrm{Bq} / \mathrm{s}$ $\mathrm{m} / \mathrm{s} \quad$ Rate, $\mathrm{h}^{-1}$

$\mathrm{Pa}$

$\begin{array}{ccccc}0 & 1.26 & -50.3 & 4583 & 1100 \\ 2 & 1.26 & -50.3 & 4583 & 1100 \\ 4 & 1.26 & -50.4 & 4592 & 1110 \\ 6 & 1.26 & -50.7 & 4620 & 1110 \\ 8 & 1.26 & -51.4 & 4678 & 1130 \\ 10 & 1.26 & -52.6 & 4787 & 1150\end{array}$

9.7

9.7

9.7

9.7

9.7

9.7

9.7

9.7

Average of All

Floors

1.26

$-52.6$

9.7

9.7

9.7

165

165

167

167

9.7

170

173

Table 25. Simulation Results for Office Building No. 2, Wind speed $=0 \mathrm{~m} / \mathrm{s}$, Minimum Outdoor Air Radon Concentration, $\mathrm{Bq} / \mathrm{m}^{3}$

$\begin{array}{cccccccc}\begin{array}{c}\mathrm{T}_{\text {in }}-\mathrm{T}_{\text {out }} \\ { }^{\circ} \mathrm{C}\end{array} & \begin{array}{c}\text { Building } \\ \text { Air Change } \\ \text { Rate, } \mathrm{h}^{-1}\end{array} & \begin{array}{c}\text { Basement } \\ \text { Pressure, } \\ \mathrm{Pa}\end{array} & \begin{array}{c}\text { Radon Entry } \\ \text { Rate, Bq/s }\end{array} & \text { Garage } & \text { Level B1 } & \text { 7th Floor } & \begin{array}{c}\text { Average } \\ \text { of All } \\ \text { Floors }\end{array} \\ -10 & 0.19 & -8.5 & 1358 & 35.0 & 10.4 & 10.3 & 10.3 \\ 0 & 0.17 & -10.3 & 1655 & 40.1 & 10.0 & 10 & 10.0 \\ 10 & 0.16 & -12.5 & 2006 & 46.6 & 9.7 & 9.7 & 9.7 \\ 20 & 0.15 & -14.7 & 2368 & 51.7 & 10.8 & 16.0 & 14.8 \\ 30 & 0.15 & -17.0 & 2736 & 57.6 & 10.2 & 18.7 & 16.9\end{array}$


Table 26. Simulation Results for Office Building No. 2, $\mathrm{T}_{\mathrm{in}}-\mathrm{T}_{\text {out }}=30^{\circ} \mathrm{C}$, Minimum Outdoor Air Intake, Wind from the North

Radon Concentration, $\mathrm{Bq} / \mathrm{m}^{3}$

$\begin{array}{cccccccc}\begin{array}{c}\text { Wind } \\ \text { Speed, } \\ \mathrm{m} / \mathrm{s}\end{array} & \begin{array}{c}\text { Building } \\ \text { Air Change } \\ \text { Rate, } \mathrm{h}^{-1}\end{array} & \begin{array}{c}\text { Basement } \\ \text { Pressure, } \\ \text { Pa }\end{array} & \begin{array}{c}\text { Radon Entry } \\ \text { Rate, Bq/s }\end{array} & \text { Garage } & \text { Level B1 } & \text { 7th Floor } & \begin{array}{c}\text { Average } \\ \text { of All } \\ \text { Floors }\end{array} \\ 0 & 0.15 & -17.0 & 2736 & 57.6 & 10.2 & 18.7 & 16.9 \\ 2 & 0.16 & -18.1 & 2906 & 60.7 & 10.3 & 18.6 & 16.8 \\ 4 & 0.18 & -21.2 & 3414 & 70.0 & 10.6 & 17.8 & 16.0 \\ 6 & 0.22 & -26.5 & 4258 & 85.6 & 10.7 & 15.3 & 14.0 \\ 8 & 0.27 & -33.8 & 5425 & 109 & 9.0 & 9.0 & 9.0 \\ 10 & 0.33 & -43.2 & 6944 & 137 & 9.0 & 9.0 & 9.0\end{array}$

Table 27. Simulation Results for Office Building No. $2, \mathrm{~T}_{\text {in }}-\mathrm{T}_{\text {out }}=30^{\circ} \mathrm{C}, 50 \%$ Outdoor Air Intake, Wind from the North

Radon Concentration, $\mathrm{Bq} / \mathrm{m}^{3}$

$\begin{array}{cccccccc}\begin{array}{c}\text { Wind } \\ \text { Speed, } \\ \mathrm{m} / \mathrm{s}\end{array} & \begin{array}{c}\text { Building } \\ \text { Air Change } \\ \text { Rate, } \mathrm{h}^{-1}\end{array} & \begin{array}{c}\text { Basement } \\ \text { Pressure, } \\ \mathrm{Pa}\end{array} & \begin{array}{c}\text { Radon Entry } \\ \text { Rate, Bq/s }\end{array} & \text { Garage } & \text { Level B1 } & \text { 7th Floor } & \begin{array}{c}\text { Average } \\ \text { of All } \\ \text { Floors }\end{array} \\ 0 & 1.50 & -16.6 & 2677 & 57.3 & 9.0 & 9.9 & 9.3 \\ 2 & 1.50 & -17.7 & 2841 & 60.4 & 9.0 & 9.7 & 9.3 \\ 4 & 1.51 & -20.7 & 3330 & 70.3 & 9.0 & 9.0 & 9.0 \\ 6 & 1.54 & -25.9 & 4164 & 85.2 & 9.0 & 9.0 & 9.0 \\ 8 & 1.59 & -33.2 & 5341 & 106 & 9.0 & 9.0 & 9.0 \\ 10 & 1.65 & -42.7 & 6872 & 134 & 9.0 & 9.0 & 9.0\end{array}$


Table 28. Simulation Results for Office Building No. $2, \mathrm{~T}_{\text {in }}-\mathrm{T}_{\text {out }}=30^{\circ} \mathrm{C}, 100 \%$ Outdoor Air Intake, Wind from the North

\section{Radon Concentration, $\mathrm{Bq} / \mathrm{m}^{3}$}

$\begin{array}{cccccccc}\begin{array}{c}\text { Wind } \\ \text { Speed, } \\ \mathrm{m} / \mathrm{s}\end{array} & \begin{array}{c}\text { Building } \\ \text { Air Change } \\ \text { Rate, } \mathrm{h}^{-1}\end{array} & \begin{array}{c}\text { Basement } \\ \text { Pressure, } \\ \mathrm{Pa}\end{array} & \begin{array}{c}\text { Radon Entry } \\ \text { Rate, } \mathrm{Bq} / \mathrm{s}\end{array} & \text { Garage } & \text { Level B1 } & \text { 5th Floor } & \begin{array}{c}\text { Average } \\ \text { of All } \\ \text { Floors }\end{array} \\ 0 & 3.00 & -16.6 & 2677 & 57.3 & 9.0 & 9.7 & 9.1 \\ 2 & 3.01 & -17.7 & 2841 & 60.4 & 9.0 & 9.6 & 9.1 \\ 4 & 3.01 & -20.7 & 3330 & 70.3 & 9.0 & 9.0 & 9.0 \\ 6 & 3.04 & -25.9 & 4164 & 85.2 & 9.0 & 9.0 & 9.0 \\ 8 & 3.09 & -33.2 & 5341 & 106 & 9.0 & 9.0 & 9.0 \\ 10 & 3.16 & -42.7 & 6872 & 134 & 9.0 & 9.0 & 9.0\end{array}$

Table 29. Simulation Results for Office Building No. $2, \mathrm{~T}_{\text {in }}-\mathrm{T}_{\text {out }}=30^{\circ} \mathrm{C}$, Fans Off, Wind from the North

Radon Concentration, $\mathrm{Bq} / \mathrm{m}^{3}$

$\begin{array}{cccccccc}\begin{array}{c}\text { Wind } \\ \text { Speed, } \\ \mathrm{m} / \mathrm{s}\end{array} & \begin{array}{c}\text { Building } \\ \text { Air Change } \\ \text { Rate, } \mathrm{h}^{-1}\end{array} & \begin{array}{c}\text { Basement } \\ \text { Pressure, } \\ \mathrm{Pa}\end{array} & \begin{array}{c}\text { Radon Entry } \\ \text { Rate, Bq/s }\end{array} & \text { Garage } & \text { Level B1 } & \text { 7th Floor } & \begin{array}{c}\text { Average } \\ \text { of All } \\ \text { Floors }\end{array} \\ 0 & 0.04 & -6.6 & 1062 & 782 & 9.0 & 191 & 104 \\ 2 & 0.04 & -7.7 & 1234 & 945 & 9.0 & 223 & 115 \\ 4 & 0.06 & -10.9 & 1757 & 1550 & 9.0 & 342 & 148 \\ 6 & 0.10 & -16.3 & 2622 & 3170 & 9.0 & 491 & 186 \\ 8 & 0.16 & -23.9 & 3834 & 11200 & 9.0 & 722 & 218 \\ 10 & 0.22 & -33.6 & 5397 & 7950 & 9.0 & 9.0 & 9.0\end{array}$


Table 30. Simulation Results for Office Building No. $2, \mathrm{~T}_{\text {in }}-\mathrm{T}_{\text {out }}=30^{\circ} \mathrm{C}$, Fans Off, Wind $45^{\circ}$ from the North Radon Concentration, $\mathrm{Bq} / \mathrm{m}^{3}$

$\begin{array}{cccccccc}\begin{array}{c}\text { Wind } \\ \text { Speed, } \\ \text { m/s }\end{array} & \begin{array}{c}\text { Building } \\ \text { Air Change } \\ \text { Rate, } \mathrm{h}^{-1}\end{array} & \begin{array}{c}\text { Basement } \\ \text { Pressure, } \\ \mathrm{Pa}\end{array} & \begin{array}{c}\text { Radon Entry } \\ \text { Rate, Bq/s }\end{array} & \text { Garage } & \text { Level B1 } & \text { 7th Floor } & \begin{array}{c}\text { Average } \\ \text { of All } \\ \text { Floors }\end{array} \\ 0 & 0.04 & -6.6 & 1062 & 782 & 9.0 & 191 & 104 \\ 2 & 0.04 & -7.4 & 1191 & 892 & 9.0 & 213 & 114 \\ 4 & 0.05 & -9.9 & 1584 & 1260 & 9.0 & 288 & 139 \\ 6 & 0.06 & -13.9 & 2234 & 1990 & 9.0 & 437 & 181 \\ 8 & 0.09 & -19.6 & 3144 & 3460 & 9.0 & 639 & 230 \\ 10 & 0.13 & -26.8 & 4314 & 7180 & 9.0 & 827 & 274\end{array}$

Table 31. Simulation Results for Office Building No. $2, \mathrm{~T}_{\text {in }}-\mathrm{T}_{\text {out }}=30^{\circ} \mathrm{C}$, Minimum Outdoor Air Intake, Wind $45^{\circ}$ from the North

Radon Concentration, $\mathrm{Bq} / \mathrm{m}^{3}$

$\begin{array}{cccccccc}\begin{array}{c}\text { Wind } \\ \text { Speed, } \\ \mathrm{m} / \mathrm{s}\end{array} & \begin{array}{c}\text { Building } \\ \text { Air Change } \\ \text { Rate, } \mathrm{h}^{-1}\end{array} & \begin{array}{c}\text { Basement } \\ \text { Pressure, } \\ \mathrm{Pa}\end{array} & \begin{array}{c}\text { Radon Entry } \\ \text { Rate, Bq/s }\end{array} & \text { Garage } & \text { Level B1 } & \text { 7th Floor } & \begin{array}{c}\text { Average } \\ \text { of All } \\ \text { Floors }\end{array} \\ 0 & 0.16 & -17.0 & 2736 & 57.6 & 10.2 & 18.7 & 16.9 \\ 2 & 0.16 & -17.8 & 2866 & 60.0 & 10.3 & 18.8 & 16.9 \\ 4 & 0.16 & -20.2 & 3249 & 66.9 & 10.5 & 18.9 & 17.0 \\ 6 & 0.18 & -24.2 & 3891 & 78.5 & 10.8 & 18.6 & 16.6 \\ 8 & 0.21 & -29.8 & 4784 & 94.9 & 10.9 & 17.1 & 15.3 \\ 10 & 0.25 & -36.9 & 5929 & 116 & 10.6 & 14.2 & 12.9\end{array}$


Table 32. Simulation Results for Office Building No. $2, \mathrm{~T}_{\mathrm{in}}-\mathrm{T}_{\text {out }}=30^{\circ} \mathrm{C}, 50 \%$ Outdoor Air Intake, Wind $45^{\circ}$ from the North

Radon Concentration, $\mathrm{Bq} / \mathrm{m}^{3}$

$\begin{array}{cccccccc}\begin{array}{c}\text { Wind } \\ \text { Speed, } \\ \mathrm{m} / \mathrm{s}\end{array} & \begin{array}{c}\text { Building } \\ \text { Air Change } \\ \text { Rate, } \mathrm{h}^{-1}\end{array} & \begin{array}{c}\text { Basement } \\ \text { Pressure, } \\ \mathrm{Pa}\end{array} & \begin{array}{c}\text { Radon Entry } \\ \text { Rate, } \mathrm{Bq} / \mathrm{s}\end{array} & \text { Garage } & \text { Level B1 } & \text { 7th Floor } & \begin{array}{c}\text { Average } \\ \text { of All } \\ \text { Floors }\end{array} \\ 0 & 1.50 & -16.6 & 2677 & 57.3 & 9.0 & 9.9 & 9.3 \\ 2 & 1.50 & -17.4 & 2801 & 59.6 & 9.0 & 9.8 & 9.3 \\ 4 & 1.50 & -19.8 & 3178 & 66.8 & 9.0 & 9.4 & 9.1 \\ 6 & 1.51 & -23.7 & 3806 & 79.0 & 9.0 & 9.0 & 9.0 \\ 8 & 1.52 & -29.2 & 4694 & 95.1 & 9.0 & 9.0 & 9.0 \\ 10 & 1.55 & -36.3 & 5839 & 116 & 9.0 & 9.0 & 9.0\end{array}$

Table 33. Simulation Results for Office Building No. $2, \mathrm{~T}_{\text {in }}-\mathrm{T}_{\text {out }}=30^{\circ} \mathrm{C}, 100 \%$ Outdoor Air Intake, Wind $45^{\circ}$ from the North

Radon Concentration, $\mathrm{Bq} / \mathrm{m}^{3}$

$\begin{array}{cccccccc}\begin{array}{c}\text { Wind } \\ \begin{array}{c}\text { Speed, } \\ \mathrm{m} / \mathrm{s}\end{array}\end{array} & \begin{array}{c}\text { Building } \\ \text { Air Change } \\ \text { Rate, } \mathrm{h}^{-1}\end{array} & \begin{array}{c}\text { Basement } \\ \text { Pressure, } \\ \mathrm{Pa}\end{array} & \begin{array}{c}\text { Radon Entry } \\ \text { Rate, } \mathrm{Bq} / \mathrm{s}\end{array} & \text { Garage } & \text { Level B1 } & \text { 7th Floor } & \begin{array}{c}\text { Average } \\ \text { of All } \\ \text { Floors }\end{array} \\ 2 & 3.00 & -16.6 & 2677 & 57.3 & 9.0 & 9.7 & 9.1 \\ 4 & 3.00 & -17.4 & 2801 & 59.6 & 9.0 & 9.7 & 9.1 \\ 6 & 3.01 & -19.8 & 3178 & 66.8 & 9.0 & 9.3 & 9.1 \\ 8 & 3.01 & -23.7 & 3806 & 79.0 & 9.0 & 9.0 & 9.0 \\ 10 & 3.03 & -29.2 & 4694 & 95.1 & 9.0 & 9.0 & 9.0 \\ & 3.05 & -36.3 & 5839 & 116 & 9.0 & 9.0 & 9.0\end{array}$


Table 34. Simulation Results for School Building, $\mathrm{T}_{\text {in }}-\mathrm{T}_{\text {out }}=30^{\circ} \mathrm{C}$, Wind Speed $=0 \mathrm{~m} / \mathrm{s}$

Outdoor Air Building Air Max. Floor Pressure, PA Radon Entry Radon Concentration, Bq $/ \mathrm{m}^{3}$ Intake, $\% \quad$ Change Rate, $\mathrm{h}^{-1} \quad$ Max. Min. Avg.

$\begin{array}{rrrrrrrrr}25 & 2.63 & -38 & -120 & -70 & 6795 & 995 & 233 & 510 \\ 50 & 2.66 & 5 & -60 & -11 & 1789 & 241 & 9 & 78 \\ 75 & 3.35 & 65 & -23 & 27 & 740 & 55 & 9 & 11\end{array}$

Table 35. Simulation Results for School Building, 50\% Outdoor Air Intake

$\mathrm{T}_{\text {in }}-\mathrm{T}_{\text {out }}$, Wind Building Air Floor Pressure, Pa Radon Entry

${ }^{\circ} \mathrm{C} \quad$ Speed $\mathrm{m} / \mathrm{s} \quad$ Change Rate, $\mathrm{h}^{-1}$ Max. Min. Avg. Rate, $\mathrm{Bq} / \mathrm{s}$

$\begin{array}{ccccccc}0 & 0 & 2.96 & 7 & -60 & -10 & 1699 \\ 0 & 10 & 3.03 & -3 & -69 & -18 & 2229 \\ 30 & 0 & 2.66 & 5 & -60 & -11 & 1789 \\ 30 & 10 & 2.75 & -5 & -70 & -20 & 2364\end{array}$

Table 36. Simulation Results for School Building, Fans Off, Wind Speed $=0 \mathrm{~m} / \mathrm{s}$

\begin{tabular}{ccccccccc}
$\mathrm{T}_{\text {in }}-\mathrm{T}_{\text {out, }}$ & $\begin{array}{c}\text { Building Air } \\
{ }^{\circ} \mathrm{C}\end{array}$ & \multicolumn{3}{c}{ Floor Pressure, Pa } & \multicolumn{2}{c}{ Radon Entry } & \multicolumn{3}{c}{ Radon Concentration, Bq $/ \mathrm{m}^{3}$} \\
-10 & 0.02 & 0.9 & 0.6 & 0.6 & 0.0 & 10.3 & 10.3 & 10.3 \\
0 & 0.0 & 0.0 & 0.0 & 0.0 & 0.0 & 10 & 10 & 10 \\
10 & 0.02 & -0.6 & -0.9 & -0.7 & 57 & 3830 & 200 & 818 \\
20 & 0.03 & -1.3 & -1.9 & -1.4 & 116 & 3960 & 212 & 880 \\
30 & 0.05 & -2.0 & -2.9 & -2.1 & 180 & 4080 & 227 & 948
\end{tabular}


Table 37. Simulation Results for School Building, Fans Off, $\mathrm{T}_{\text {in }}-\mathrm{T}_{\text {out }}=0{ }^{\circ} \mathrm{C}$, Wind from the North

\begin{tabular}{|c|c|c|c|c|c|c|c|c|}
\hline Wind & Building Air & \multicolumn{3}{|c|}{ Floor Pressure, $\mathrm{Pa}$} & Radon Entry & \multicolumn{3}{|c|}{ Radon Concentration, $\mathrm{Bq} / \mathrm{m}^{3}$} \\
\hline $\begin{array}{c}\text { Speed } \\
\mathrm{m} / \mathrm{s}\end{array}$ & Change Rate, $\mathrm{h}^{-1}$ & Max. & Min. & Avg. & Rate, $\mathrm{Bq} / \mathrm{s}$ & Max. & Min. & Avg. \\
\hline 0 & 0.0 & 0.0 & 0.0 & 0.0 & 0.0 & 10 & 10 & 10 \\
\hline 2 & 0.03 & 0.3 & -0.2 & -0.2 & 13 & 491 & 10 & 155 \\
\hline 4 & 0.08 & 0.7 & -1.2 & -1.0 & 72 & 933 & 10 & 365 \\
\hline 6 & 0.13 & 1.5 & -2.7 & -2.3 & 172 & 1200 & 10 & 488 \\
\hline 8 & 0.19 & 2.7 & -4.9 & -4.1 & 312 & 1430 & 10 & 608 \\
\hline 10 & 0.25 & 4.1 & -7.7 & -6.5 & 491 & 1660 & 10 & 719 \\
\hline
\end{tabular}

Table 38. Simulation Results for School Building, Fans Off, $\mathrm{T}_{\text {in }}-\mathrm{T}_{\text {out }}=30^{\circ} \mathrm{C}$, Wind from the North

\begin{tabular}{ccccccccc}
$\begin{array}{c}\text { Wind Speed } \\
\mathrm{m} / \mathrm{s}\end{array}$ & $\begin{array}{c}\text { Building Air } \\
\text { Change Rate, } \mathrm{h}^{-1}\end{array}$ & \multicolumn{3}{c}{ Max. } & Min. & Avg. & \multicolumn{2}{c}{ Radon Entry } \\
Rate, Bq/s & \multicolumn{2}{c}{ Radon Concentration, Bq $/ \mathrm{m}^{3}$} \\
0 & 0.05 & -2.0 & -2.9 & -2.1 & 180 & 4080 & 227 & 948 \\
2 & 0.05 & -2.0 & -3.0 & -2.3 & 188 & 3200 & 228 & 975 \\
4 & 0.08 & -1.3 & -3.8 & -3.1 & 243 & 2250 & 101 & 856 \\
6 & 0.14 & -0.2 & -5.3 & -4.5 & 346 & 1880 & 16 & 804 \\
8 & 0.19 & 1.4 & -7.5 & -6.5 & 493 & 1860 & 9 & 832 \\
10 & 0.25 & 3.4 & -10.5 & -9.0 & 682 & 1980 & 9 & 893
\end{tabular}




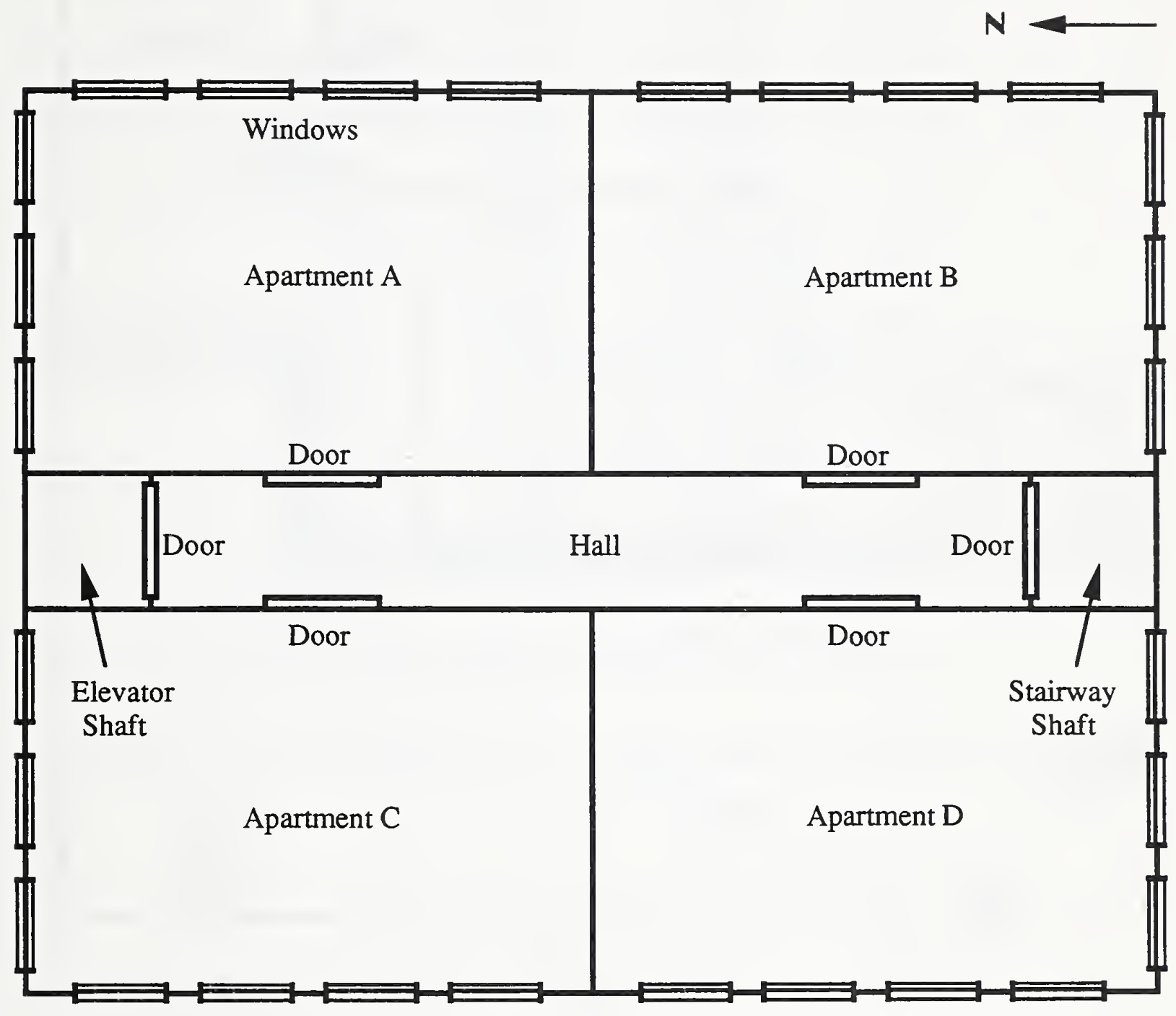

Figure 1 Typical Floor Plan of Apartment Building 


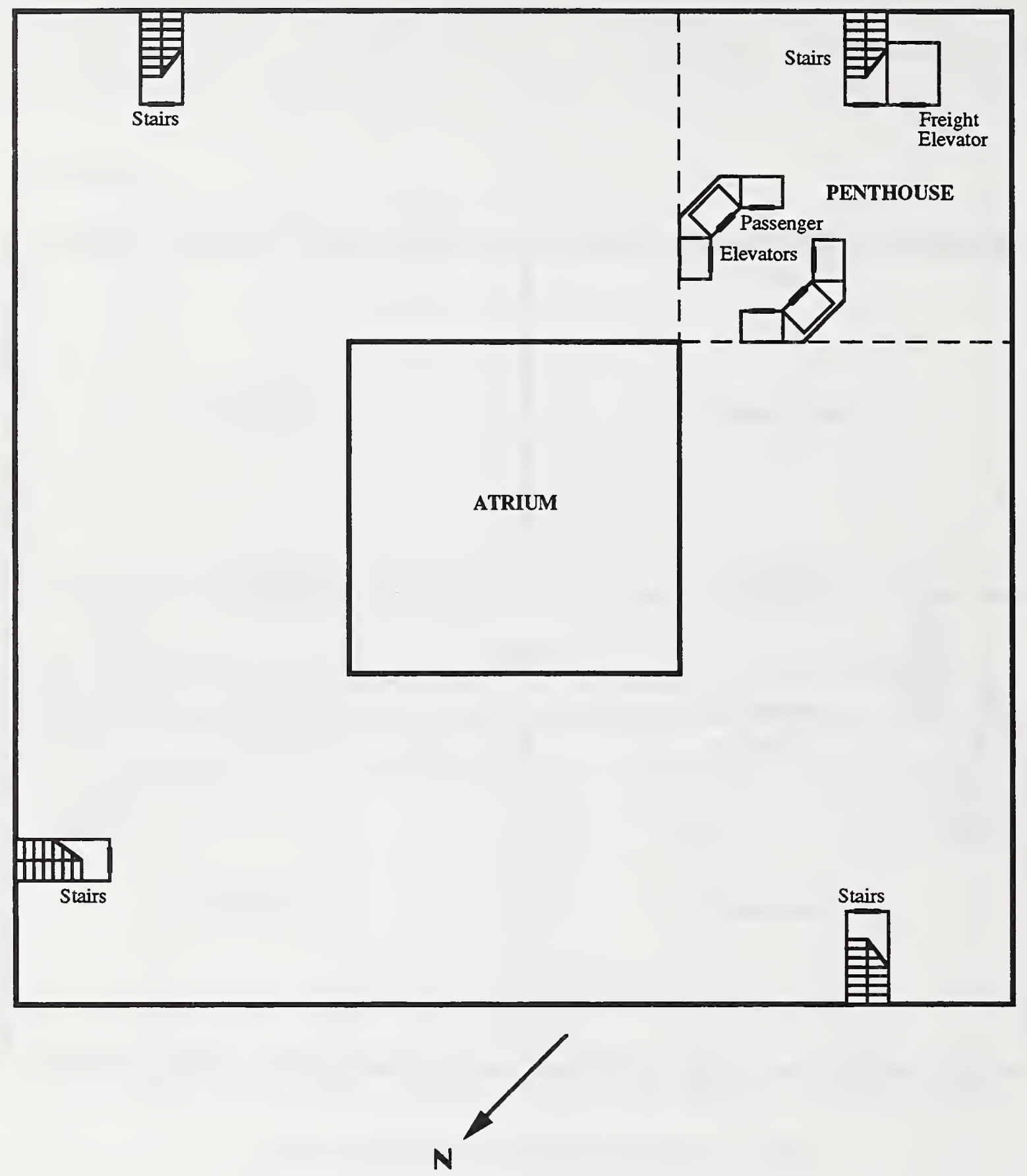

Figure 2 Level-5 Floor Plan of Office Building No. 1 


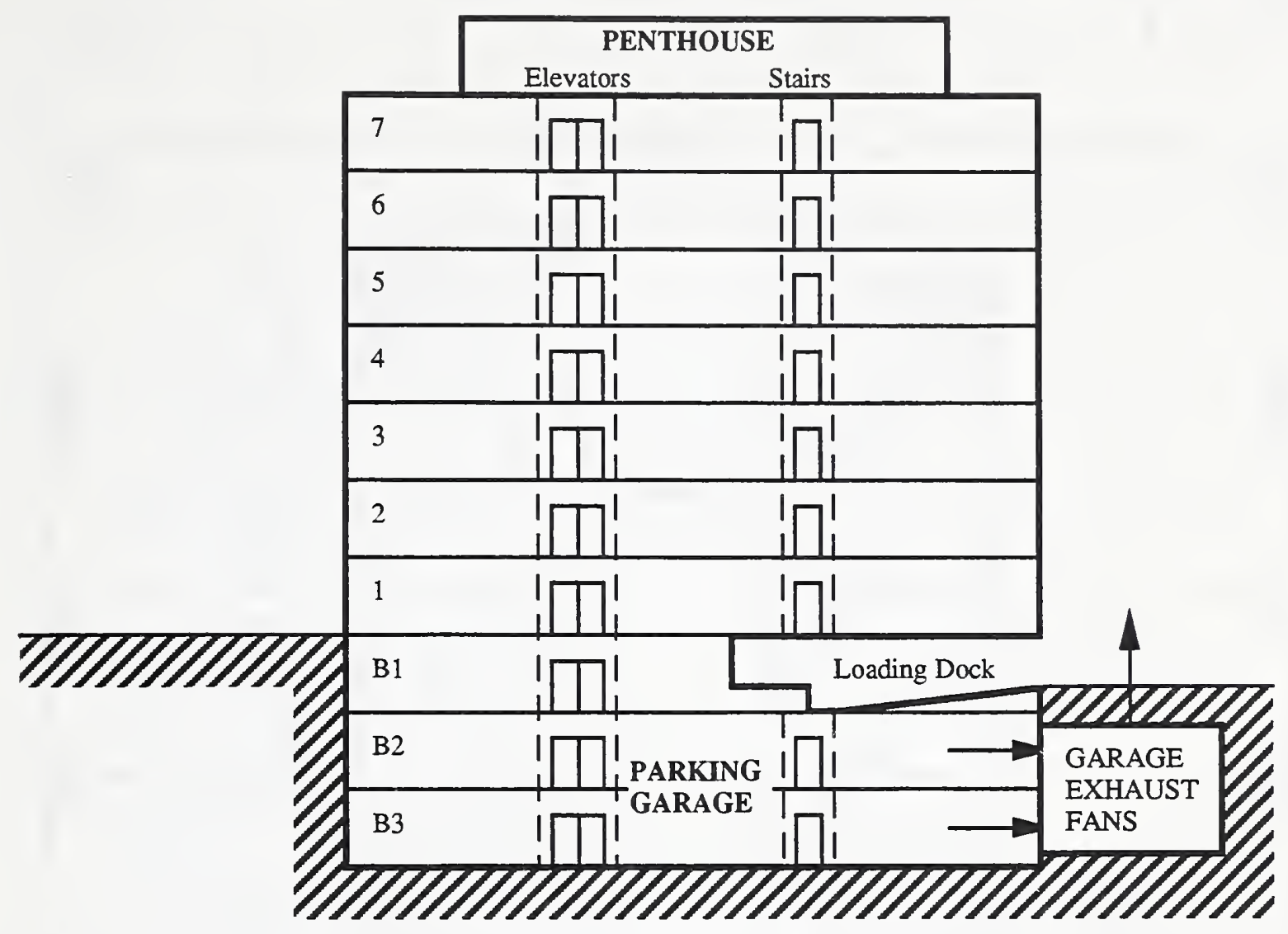

Figure 3 Schematic Elevation of Office Building No. 2

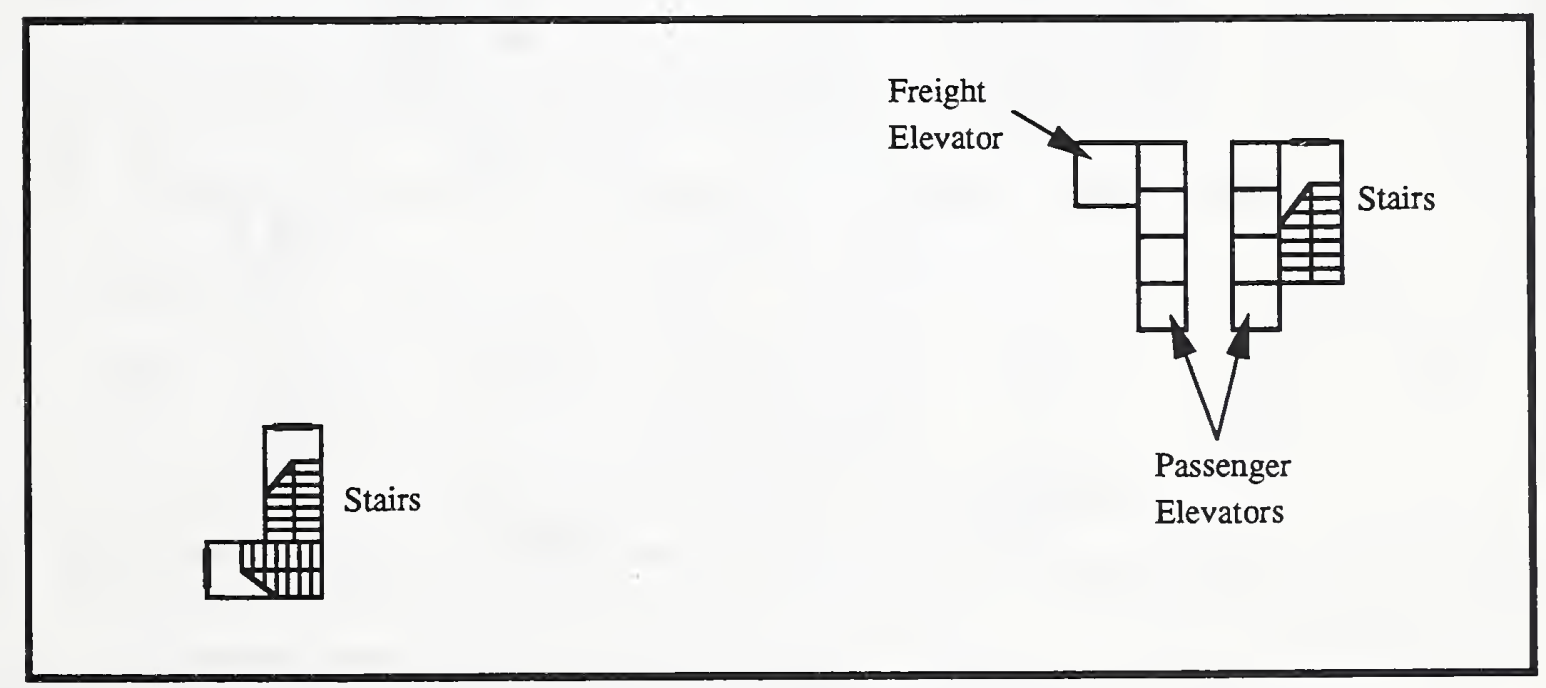

Figure 4 Typical Floor Plan of Office Building No. 2 


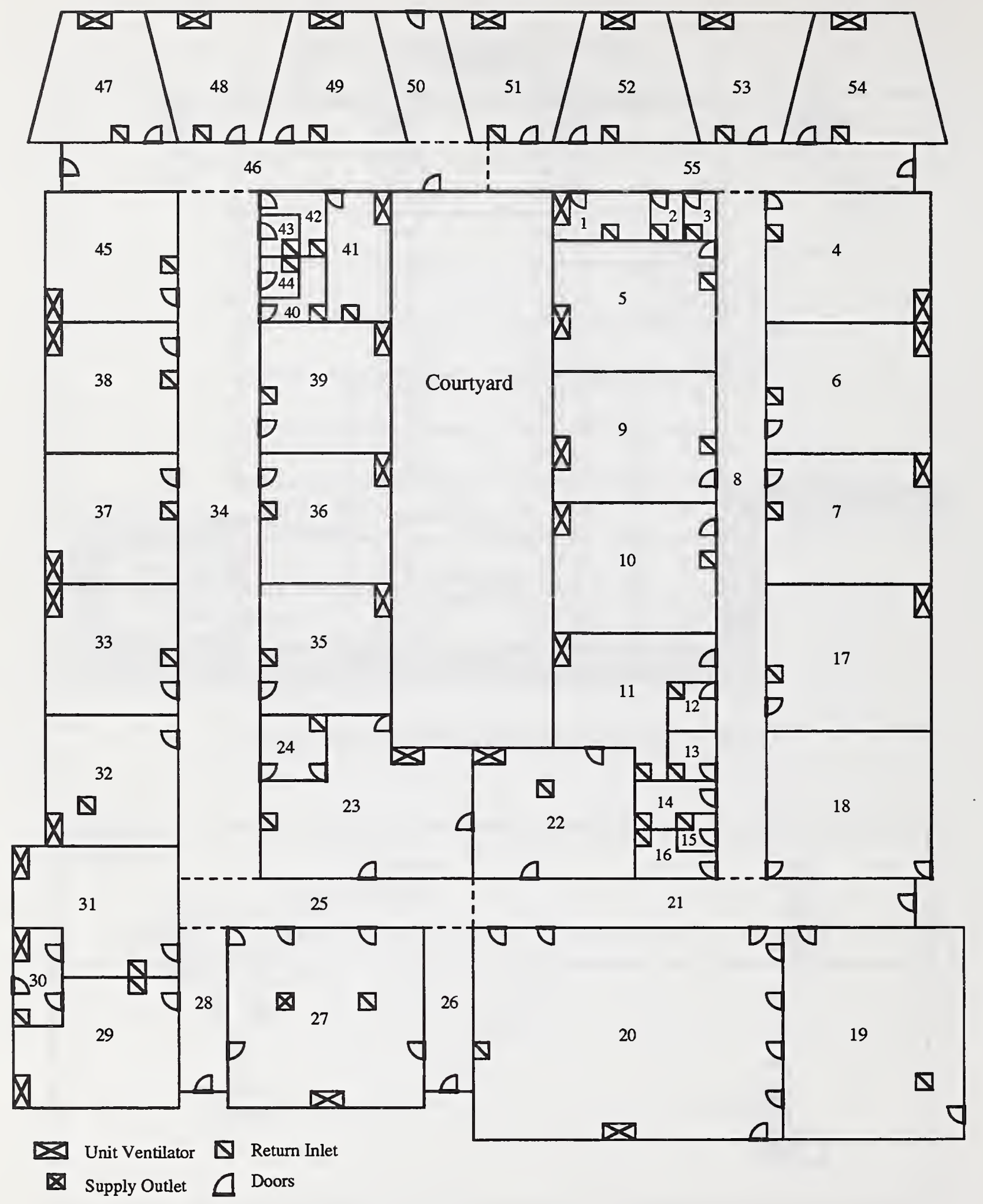

Figure 5 Floor Plan of School Building 




Radon concentrations in $\mathrm{Bq} / \mathrm{m}^{3}$ for each zone are in italics.

Pressure differences in Pa between the floor of each zone and the outdoors are in parentheses.

Simulation conditions: $50 \%$ outdoor air intake, $0 \mathrm{~m} / \mathrm{s}$ wind speed, $0{ }^{\circ} \mathrm{C}$ temperature difference

Figure 6 Radon Concentrations and Zone Pressures in the School Building 



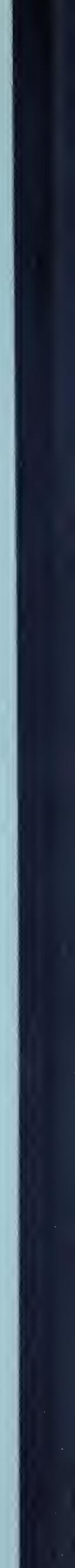

